\title{
Occurrence, characteristics and formation mechanisms of methane generated micro-pockmarks in Dunmanus Bay, Ireland
}

\author{
M.T. Szpak ${ }^{\mathrm{a}}$, X. Monteys ${ }^{\mathrm{b}}$, S.S. O’Reilly ${ }^{\mathrm{a}, 1}$, M.K.S. Lilley ${ }^{\mathrm{d}}$, G.A. Scott ${ }^{\mathrm{c}}$, K.M. Hart $^{\mathrm{a}, 2}{ }^{\text {, }}$ \\ S.G. McCarron ${ }^{c}$, B.P. Kelleher ${ }^{\text {a,* }}$ \\ a School of Chemical Sciences, Dublin City University, Glasnevin, Dublin 9, Ireland \\ ${ }^{\mathrm{b}}$ The Geological Survey of Ireland, Beggars Bush, Haddington Road, Dublin 4, Ireland \\ c Geography Department, National University of Ireland Maynooth, Rhetoric House, Maynooth, Ireland \\ d School of Biological and Chemical Sciences, Queen Mary University of London, Mile End, London E1 4NS, UK
}

\section{A R T I C L E I N F O}

\section{Article history:}

Received 19 December 2014

Received in revised form

1 April 2015

Accepted 27 April 2015

Available online 30 April 2015

Keywords:

Shallow gas

Marine pockmarks

Methane

Geomorphology

Pockmark formation mechanisms

Benthic community

Geochemistry

\begin{abstract}
A B S T R A C T
A small gas pockmark field in Dunmanus Bay, SW Ireland was surveyed and ground-truthed to assess its activity, geomorphology, explore its formation mechanisms and to investigate its potential influence on the benthic community. The field consisted of 121 circular, shallow units ranging from 5 to $17 \mathrm{~m}$ in diameter and not exceeding $1 \mathrm{~m}$ in relief. Sub-bottom profiles revealed broad acoustic signatures typical of shallow gas accumulation in the subsurface in addition to vertically elongated signals of ascending bubbles captured in the echo sounder data. The pockmarks show strong correlation with the depth of sub-surface gas fronts. However methane concentrations in the water column and directly above the features were close to typical marine, background values and did not exceed $15 \mathrm{nM}$. This suggests a very mild, periodic venting scenario. Sediment core samples revealed permeable sandy layers with slightly elevated methane concentrations indicative of stratified, diffusive flow. Pore-water sulphate and chloride data show no sign of pore water freshening and thus suggest that methane gas is the sole fluid responsible for formation of these pockmarks. Benthic infauna distributions showed reduced diversity in pockmarked regions, primarily influenced by the sediment composition. Few species utilising chemosymbiotic associations were identified, and there was little indication of a community influenced by methane venting in Dunmanus Bay.
\end{abstract}

(c) 2015 Elsevier Ltd. All rights reserved.

\section{Introduction}

Fluid flow in the marine subsurface is a known but poorly understood and difficult to observe phenomenon. Pockmarks are sub-circular, shallow depressions formed predominantly in soft, fine-grained substrates, and are widely considered as geo-morphological expressions of fluid expulsion through the sediment (King and MacLean, 1970). They occur in the majority of aquatic environments including lakes, deltas and estuaries (e.g. Berkson

\footnotetext{
* Corresponding author.

E-mail addresses: szpakm@dcu.ie (M.T. Szpak),

Xavier.Monteys@gsi.ie (X. Monteys), oreillys@mit.edu (S.S. O’Reilly),

m.lilley@qmul.ac.uk (M.K.S. Lilley), gillian.scott@nuim.ie (G.A. Scott),

k.hart@qmul.ac.uk (K.M. Hart), Stephen.mccarron@nuim.ie (S.G. McCarron),

brian.kelleher@dcu.ie (B.P. Kelleher).

${ }^{1}$ Department of Earth, Atmospheric and Planetary Sciences, Massachusetts Institute of Technology, Cambridge, MA, USA

${ }^{2}$ School of Biological and Chemical Sciences, Queen Mary University of London, Mile End, London E1 4NS, UK.
}

and Clay, 1973; Hovland et al. 1997; Brothers et al. 2012). In most reported cases of pockmarks around the globe the fluid involved is methane gas and thus they are frequently referred to as 'gas pockmarks' (Judd and Hovland, 2007). Although gas expulsion is the most common formation mechanism of these features, compacted pore water (Harringotn, 1985) and groundwater expulsions (Christodoulou et al., 2003), iceberg scouring (Pilcher and Argent, 2007), as well as anthropogenic activities such as trawling (Fader, 1991) have also been proposed as viable alternatives. The presence of pockmarks often indicates an active fluid system and thus, they are frequently targeted by the oil and gas industry (Hedberg, 1980). However, seeps are also considered geo-hazards and obstacles for underwater installations as they weaken the sediment structure and alter the morphology of the seabed. A comprehensive understanding of these marine seepage features and their contributions to the food web (Straughan, 1982), local fauna (Dando et al., 1991), nutrient cycles (Wildish et al., 2008), and the carbon cycle in particular (Judd, 2003, 2004) remains elusive.

Surveying efforts of Integrated Mapping For Sustainable 
Development of Ireland's Marine Resources (INFOMAR) and its predecessor, the Irish National Seabed Survey (INSS), over the past 10 years have revealed pockmarks and other seepage related structures in numerous locations in the Irish Exclusive Economic Zone, i.e. on the Malin Shelf (Monteys et al., 2008, 2009) and in the Irish Sea (Croker et al., 2005; O'Reilly et al., 2014). Pockmarks in Dunmanus Bay were identified in 2007 during a multibeam mapping survey carried out by the RV Celtic Voyager as part of the INFOMAR programme. However, the relatively low resolution of the data precluded detailed insight into the morphology of these features. In April 2009 the RV Celtic Voyager acquired very high resolution bathymetry data that permitted better insight into the morphology and distribution of the Dunmanus Bay pockmarks (Szpak et al., 2009; Monteys et al., 2010). In this paper, we report findings of the first ground-truthing survey of this pockmark field, the activity and nature of these features, and investigate their influence on benthic communities.

\section{Study area}

Dunmanus Bay is located off the South-West of Ireland, south of the larger and better known Bantry Bay (County Cork). The bay is $7 \mathrm{~km}$ wide from Sheep's Head to Three Castles Head and $25 \mathrm{~km}$ long from its mouth. It is a rias setting with only one small river, the Durrus, and several streams draining into the bay. Water depth ranges from below $20 \mathrm{~m}$ in the inner bay to over $70 \mathrm{~m}$ at its mouth (Fig. 1). The area is strongly influenced by coastal upwelling but tidal activity is low as Dunmanus Bay is out of the main tidal flow (Edwards et al., 1996).

Favourable thermal fronts and adequate nutrient concentrations support high levels of phytoplankton production in these waters and seasonal blooms are common (Raine et al., 1990). Notably, blooms of Gyrodinium aureolum (dinoflagellate responsible for the so called "red tides") are frequent in these waters affecting local aquaculture (Jenkinson and Connors, 1980; Roden et al., 1980, 1981). The benthic fauna of Dunmanus Bay remains largely unstudied, with only intertidal species such as sea lettuce (Ulva lactuca), snails (Nucella lapillus), barnacles (Semibalanus balanoides, Chthamalus montagui), mussels (Mytilus spp.) and limpets (Patella vulgata, Patella aspera) documented (Cross and Southgate, 1983).

The bedrock geology of Dunmanus Bay has not been studied per se but inferred from the geology of bordering landmasses in the 1850s by Jukes (1864) and Jukes et al. (1861) and more recently by Naylor (1975), Naylor and Sevastopulo, (1993) and MacCarthy (2007). Both Bantry and Dunmanus Bay lie in the South Munster Basin separated by the Sheep's Head anticline. The major

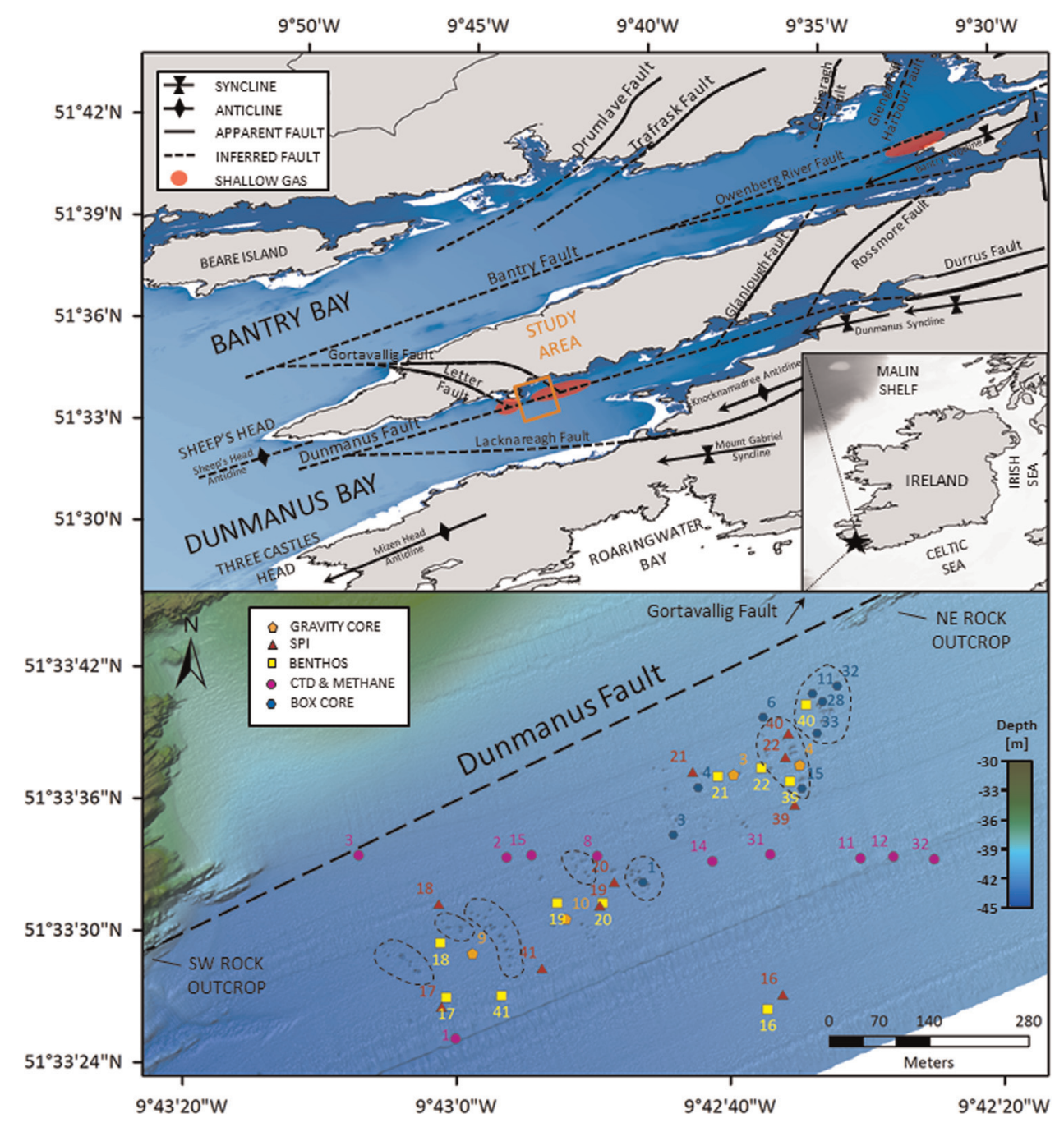

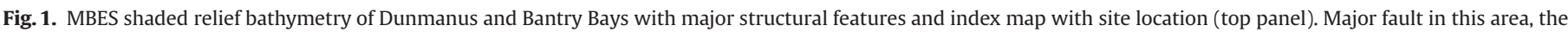

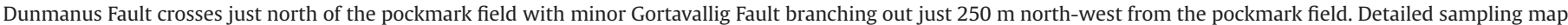
(bottom panel) shows the location of sediment and water column sampling stations. Dashed shapes delineate major pockmark clusters. (DOUBLE COLUMN). 
sedimentation controlling fault in this area is the Dunmanus Fault (DF) crossing the entire Bay parallel to the landmass (Fig. 1). Two major branchings off this fault occur in the vicinity of a pockmark field area: the Gortavallig Fault (GVF) and the Letter Fault (LF). Moreover, there are several minor faults in the northern part of the Dunmanus syncline separate from the DF, notably the Rossmore Fault (RF) and the Glanlough Fault (GF). Faults are often associated with fluid migration provided that source rocks are present and thermal conditions favour hydrocarbon generation (e.g. Kutas et al., 2004). Early Carboniferous formations are abundant in the area and contain, in places, organic-rich shales, so called "marine bands" and "Alluvium, Peat-bog" (Jukes, 1864 and Hunt, 1858). The surface sediments in Dunmanus Bay are predominantly muddy sands with a small gravel component. Sub bottom and discrete sediment core data suggests that near surface sediments consist of mainly fine to coarse sands with varying contribution of clays and silts (Szpak et al., 2009). These recent sediments overlie a prominent seismic signature similar to that discovered in Bantry Bay. Plets et al. (2014) interpreted it as transgressive surface, developed pre-11 ka, underlying intertidal-estuarine sediments. As Dunmanus and Bantry Bays have likely experienced the same recent environmental history and share numerous similarities in acoustic data sets, typical of drowned valleys, we suspect that signatures observed in data presented herein represent the extension of the palaeo beach identified in their work.

\section{Materials and methods}

\subsection{Bathymetry}

Two Bathymetric datasets have been used in this study. The first, covering the entire bay was acquired in 2007 as part of the INFOMAR programme on-board the RV Celtic Voyager using a Kongsberg-Simrad EM1002 multibeam echo-sounder, with an operational frequency of $93-98 \mathrm{kHz}$ and pulse length of $0.2 \mathrm{~ms}$. The second dataset was acquired in 2009, focusing around the pockmark field, using a Kongsberg-Simrad EM3002D multibeam echo-sounder, with an operational frequency of ca. $240 \mathrm{kHz}$ and low survey speed (2-3 knots). Resulting bathymetric terrain models were gridded at $1 \times 1 \mathrm{~m}$. Pockmark density was calculated using ArcGIS 10.1 with Spatial Analyst Tool add-on (ESRI) (Silverman, 1986).

\subsection{Pockmark morphology}

Pockmarks were manually delineated using Fledermaus software package (Quality Positioning Services B.V.). Craters were measured along N-S (width), W-E (length), NW-SE and SW-NE axes. Pockmark edge was determined by measuring the slope of the side walls with cut-off point at $2.0^{\circ}$. The depth was calculated by subtracting averaged wall edge depths from the deepest point within the crater. Shared walls of composite pockmarks were not included in calculations. Perimeter and surface area were calculated as for ellipsoids. Volume was calculated as for half-spheroids.

\subsection{Sub-bottom profiler}

Sub-bottom profile data were acquired using a heave-corrected SES Probe $50003.5 \mathrm{kHz}$ transceiver in conjunction with a hullmounted $4^{\circ} \times 4^{\circ}$ transducer array. Acquisition parameters, data logging and interpretation were carried out using the CODA Geokit suite. Both Raw Navigation string and Heave Compensation string were fed into the Coda DA200 system.

\subsection{Water column sampling}

Water column samples were collected with Niskin bottles mounted on a SBE 32 Carousel Water Sampler (Sea-Bird Electronics Inc., USA). During descent the Conductivity, Temperature and Depth (CTD) profiles were recorded to identify oceanographic background conditions and allow sampling of the water column in a more informative manner. Upon retrieval, samples were transferred immediately to $125 \mathrm{~mL}$ serum bottles and crimp sealed with a gas-tight, thick, butyl rubber septum. All water samples were poisoned with a saturated mercuric chloride $\left(\mathrm{HgCl}_{2}\right)$ solution to inhibit microbial activity and stored at $2-4{ }^{\circ} \mathrm{C}$ until analysis. Samples were analysed according to the modified head-space method with salting-out as described by Gal'chenko et al. (2004). Briefly, samples were boiled in a water bath for $1 \mathrm{~h}$ on the day of analysis to ensure full desorption of methane. The methane content from head-space was determined on shore after the cruise on a Carlo Erba gas chromatograph equipped HP-PLOT Q capillary column (30 $\mathrm{m} \times 0.32 \mathrm{~mm}$ i.d., $20 \mu \mathrm{m}$ film thickness) and flame ionisation detector (GC-FID). The detector temperature was set to $225^{\circ} \mathrm{C}$ and He was used as carrier gas. Samples were quantified based on the methane gas standard response as described in Gal'chenko et al. (2004). Method robustness was tested with methane standards across a range of concentrations and yielded with a precision of $\pm 0.5 \mathrm{nM}, n=4$ for concentrations $<25 \mathrm{nM}$. Chlorophyll a concentrations were derived from fluorescence measurements recorded during all CTD casts. The fluorescence sensor was calibrated for Chlorophyll a concentrations ranging from 0.04 to $200 \mu \mathrm{g} / \mathrm{l}$.

\subsection{METS sensor}

A METS sensor (Franatech GmbH, Germany) was mounted on the Sea-Bird 911 CTD (Sea-Bird Electronics Inc., USA) unit. The CTD's water pump feeding tubes were modified to ensure that both sensors analysed the same representative water sample. The sensor was calibrated by the manufacturer for methane concentrations ranging from 2 to $200 \mathrm{nM}$ in a temperature range from 2 to $20^{\circ} \mathrm{C}$. An equilibration test was performed to assess the minimal time necessary to reach baseline signal after saturation. Lag time varied between 200 and 300 s depending on saturation conditions (350 and $700 \mathrm{nM}$ respectively). The sensor was deployed with the CTD and held $5 \mathrm{~m}$ above the seabed until the signal stabilized. Between deployments the sensor was kept powered on and immersed in running surface water to minimise humidity and temperature variability.

\subsection{Sediment sampling}

Sediment samples for benthos analysis were collected with a Day Grab sampler $\left(0.1 \mathrm{~m}^{2}\right)$. Five replicate samples were taken per site. Sediment samples for bulk parameters analysis were collected using box and gravity corers. Samples locations are shown in Table1. Vessel position was determined using DGPS with horizontal accuracy of $<1 \mathrm{~m}$. Sample position was recorded when the sampler contacted with the seabed to account for vessel drift. Final sample coordinates were corrected for the offset between DGPS antenna and sampling equipment position. Cumulative vessel and sampling uncertainty is estimated to be $\pm 10 \mathrm{~m}$.

\subsection{Bulk parameters}

Upon retrieval, box and gravity core samples were transferred to an argon-purged glove box and a redox potential $\left(E_{\mathrm{h}}\right)$ measurement was taken with the use of a temperature compensated push-in Pt electrode with $\mathrm{Ag} / \mathrm{AgCl}$ reference junction (SCHOTT). 
Table 1

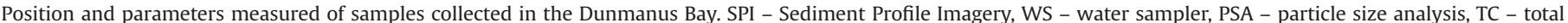

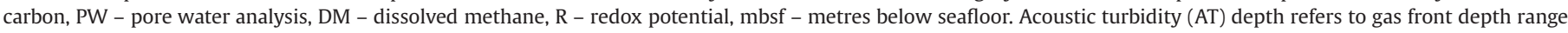

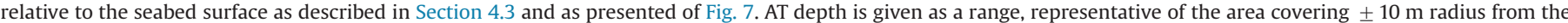

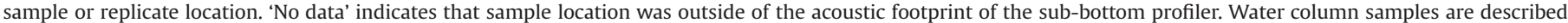
depending on whether they were collected from outside or inside of the pockmark field (PF) as constrained by sub-bottom date presented on Fig. 7.

\begin{tabular}{|c|c|c|c|c|c|c|c|c|c|c|}
\hline \multirow[t]{2}{*}{ Site } & \multicolumn{7}{|c|}{ Grain size $(\mu \mathrm{m})$} & \multirow[t]{2}{*}{ Gravel } & \multirow[t]{2}{*}{ Sand } & \multirow[t]{2}{*}{ Silt/clay } \\
\hline & $>2000$ & $>1000$ & $>500$ & $>250$ & $>125$ & $>63$ & $<63$ & & & \\
\hline 17 & 14.9 & 13 & 10.4 & 8.9 & 8.9 & 11.2 & 32.7 & 14.9 & 52.4 & 32.7 \\
\hline 18 & 7.4 & 9.9 & 9.7 & 8.1 & 9.2 & 17.1 & 38.6 & 7.4 & 54 & 38.6 \\
\hline 41 & 19.2 & 10.2 & 10.2 & 9.4 & 9 & 15.6 & 26.4 & 19.2 & 54.4 & 26.4 \\
\hline 19 & 6.3 & 12.3 & 14.1 & 11.7 & 10.8 & 12.5 & 32.3 & 6.3 & 61.4 & 32.3 \\
\hline 20 & 12.3 & 9.8 & 8.7 & 7.9 & 6.9 & 15.7 & 36 & 12.3 & 49 & 36 \\
\hline 21 & 15.1 & 10.9 & 9.1 & 7.6 & 9.3 & 14 & 33.8 & 15.1 & 50.9 & 33.8 \\
\hline 22 & 6 & 12.1 & 12.4 & 11 & 10.8 & 13.6 & 34.1 & 6 & 59.9 & 34.1 \\
\hline 39 & 5.3 & 6.9 & 39 & 5.1 & 6.9 & 12.1 & 24.7 & 5.3 & 70 & 24.7 \\
\hline 16 & 2.2 & 5.5 & 5.8 & 4.7 & 14.3 & 31.1 & 36.4 & 2.2 & 61.4 & 36.4 \\
\hline 40 & 15.4 & 12.8 & 9.7 & 8.4 & 9.3 & 11.6 & 32.8 & 15.4 & 51.8 & 32.8 \\
\hline
\end{tabular}

The electrode was routinely checked for sulphide poisoning and tested for reproducibility between measurement series with saturated quinhydrone $\mathrm{pH}$ buffer solutions $(\mathrm{pH}=4.0$ and 7.0 , with expected $\left.\Delta E_{\mathrm{h}}=172 \pm 4 \mathrm{mV}\right)$. Sediment cores $\left(10 \mathrm{~cm}^{3}\right)$ for interstitial gas analyses were collected with cut-off syringes and transferred to head-space vials and processed similarly to water samples. Pore waters for sulphate and chloride analysis were extracted by centrifugation and stored at $2-4{ }^{\circ} \mathrm{C}$. Concentration of these ions was determined on-shore by ion chromatography according to standard methodology. Granulometric analysis was performed on dried sediment from each benthos station. Approximately $100 \mathrm{~g}$ of sediment was sieved through a series of Wentworth graded sieves (McMahon et al., 1996).

\subsection{Benthos sampling}

A Perspex core was taken from each sample for on-shore meiofaunal assemblage analysis, the remaining sample was sieved on a $1 \mathrm{~mm}$ mesh sieve and the retained macrofaunal assemblage was preserved in a $10 \%$ buffered formalin solution. All meiofaunal and macrofaunal assemblages were sorted under a microscope into four main groups: Polychaeta, Mollusca, Crustacea and Others which consisted of echinoderms, nematodes, nemerteans, cnidarians and other phyla. The taxa were identified to a species level where possible.

Univariate and multivariate statistical analyses were carried out on the combined replicate station-by-station faunal data. The following diversity indices were calculated: Pielou's Evenness index (J), (Pielou, 1977) and Shannon-Wiener diversity index $\left(H^{\prime}\right)$, (Pielou, 1977). The PRIMER ${ }^{\circledR}$ programme (Clarke and Warwick, 2001) was used to carry out multivariate analyses. All species/ abundance data were fourth root transformed and used to prepare a Bray-Curtis similarity matrix in PRIMER ${ }^{\circledR}$. The fourth root transformation was used in order to down-weigh the importance of the highly abundant species and to allow the mid-range and rarer species to play a part in the similarity calculation. The BrayCurtis similarity matrix was subjected to a non-metric multi-dimensional scaling (MDS) algorithm and cluster analysis (Kruskal and Wish, 1978).

\subsection{Sediment profile imaging}

Sediment profile images were taken in five replicates at the same locations as benthic samples with a Sediment Profile Imagery camera (SPI; AQUAFACT International Services Ltd., Ireland). SPI cameras permit in situ images of the undisturbed sediment water interface to be obtained, which is impossible to obtain ex situ mainly due to sediment disruption and compaction during sampling with use of conventional apparatus (Somerfield and Clarke, 1997). SPI cameras mounted on a frame are slowly lowered on to the seabed to minimise sediment disruption and then a hydraulic or gravity based system is triggered from the vessel to insert the prism into the seabed.

\section{Results and discussion}

\subsection{Water column and seabed sediments bulk parameters}

Thermo and haloclines were well defined with an average depth of $11 \mathrm{~m}$. Average water temperature just below the thermocline was $10.6{ }^{\circ} \mathrm{C}$ and $9.6^{\circ} \mathrm{C}$ at near bottom. Dunmanus Bay is fed by only a few streams and a relatively small river (River Durrus). It therefore experiences little freshwater influence and has marine water column characteristics close to that of the open sea. The salinity (in PSU) reaches average open ocean values and generally follows the thermocline fronts with surface water reaching a salinity of 34.92 and increasing to 35.05 below the pycnocline and 35.08 in near bottom waters. The influence of weak coastal upwelling was observed in the water column but, as in the Bantry Bay, the strongest upwelling is believed to be observed in the mouth of the bays rather than their interior (Elliott and Clarke, 1991). Dunmanus Bay experiences semi-diurnal tidal cycles but overall tidal activity is low as the bay is out of the main tidal flow.

Chlorophyll $a(\mathrm{Chl} a)$ concentrations were similar at all stations and varied between $2.33-3.33 \mu \mathrm{g} / \mathrm{l}$. A Chl $a$ maximum was present at an average depth of $17 \mathrm{~m}$. The concentration of phytoplankton started to increase just below the pycnocline, with the lower boundary located around $30 \mathrm{~m}$. A slight decline in concentrations $\left(R^{2}=0.41, n=9\right)$ can be observed across the $\mathrm{W}$ to $\mathrm{E}$ transect, suggesting increased plankton activity towards land, possibly due to nutrient runoff into the bay. There is no plankton data published for Dunmanus Bay, but these observations are consistent with those from a previously reported study of neighbouring Bantry Bay (Gribble et al., 2007).

Surface sediments at all stations are similar across all Wentworth size classes, comprising mainly fine to coarse sands with a small percentage of gravel and with a significant, but not dominant, silt/clay component (Table 2). The percentage of gravel varied from $2.2 \%$ to $19.2 \%$ and more gravel was found in those stations located in the vicinity of rock outcrops suggesting an erosional 
Table 2

Particle size distribution of surface sediments in the Dunmanus Bay pockmark field measured at the biological stations. Sands are the dominant substrate type with significant proportions of silts and clays, and occasional gravel. Control station is marked with an underline.

\begin{tabular}{lllll}
\hline Station & Species & Individuals & Evenness & Diversity \\
\hline$\frac{16}{17}$ & 77 & 908 & 0.58 & 3.66 \\
18 & 46 & 632 & 0.57 & 3.14 \\
19 & 39 & 1462 & 0.37 & 1.96 \\
20 & 43 & 1878 & 0.37 & 2.01 \\
21 & 34 & 382 & 0.61 & 3.09 \\
22 & 23 & 568 & 0.35 & 1.60 \\
39 & 43 & 786 & 0.36 & 1.94 \\
40 & 35 & 929 & 0.42 & 2.17 \\
41 & 32 & 741 & 0.40 & 2.02 \\
\hline
\end{tabular}

origin, rather than alluvial transportation. Sands are fairly evenly distributed between the five sand size classes (grand mean 11.3\%, $n=50$ ) with the finer grain size fractions being slightly more
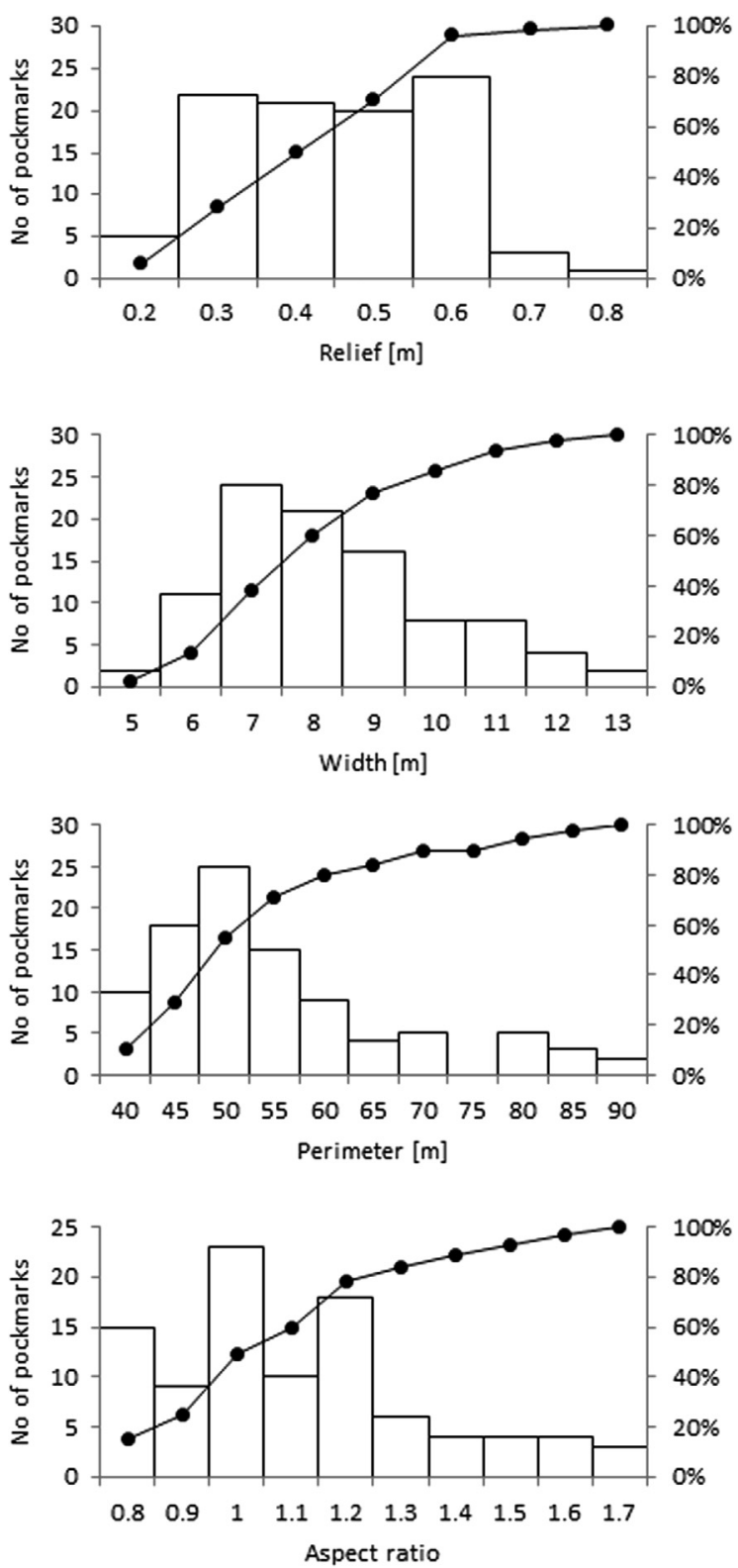

abundant (11.2-31.1\%). Silt and clay comprised approximately a third (mean $32.8 \%, n=10$ ) of the total weight of the sediment.

Overall, variability in water column and sediment characteristics in the study area was low and we conclude that Dunmanus Bay pockmark field is a relatively homogenous habitat. The uncertainties arising from variability in plankton distribution and abundance, water column structure are negligible and thus, do not affect the benthic community structure (Clarke and Green, 1988). Although particle size distribution is fairly similar in all stations, some minor effects on the benthos distribution were observed. These are discussed in more detail in Section 4.6.

\subsection{Pockmark morphology and distribution}

Dunmanus Bay pockmark field contains 121 pockmark features. Many of them $(n=50)$ have a composite morphology with at least one or more of the side walls shared with other pockmarks and having significantly lower slope. In most cases however, individual pockmark units can be distinguished and almost all $(n=114)$ of the features are sub-circular. The largest composite pockmark
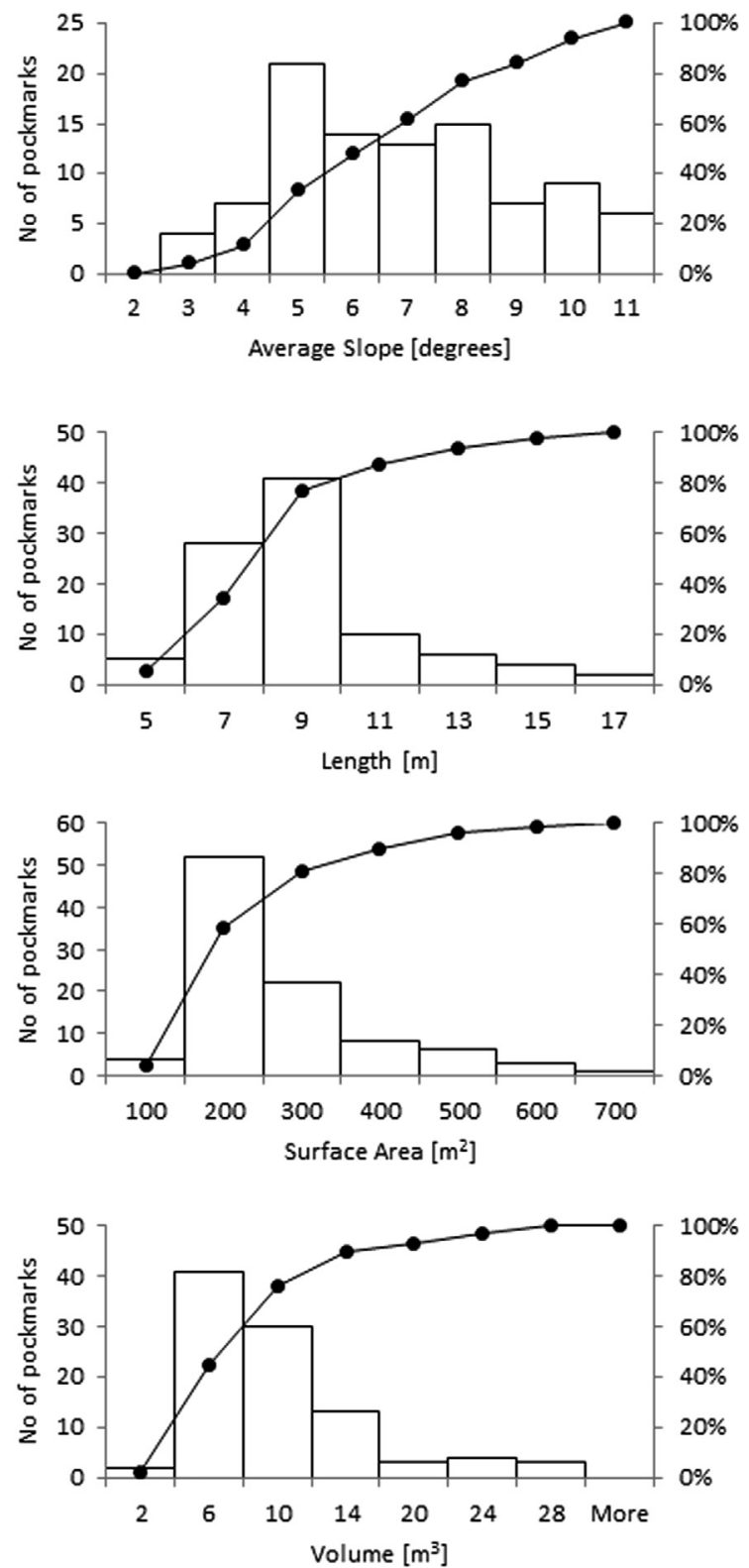

Fig. 2. Histograms and cumulative frequency curves depicting basic morphological characteristics of Dunmanus Bay pockmarks (DOUBLE COLUMN). 


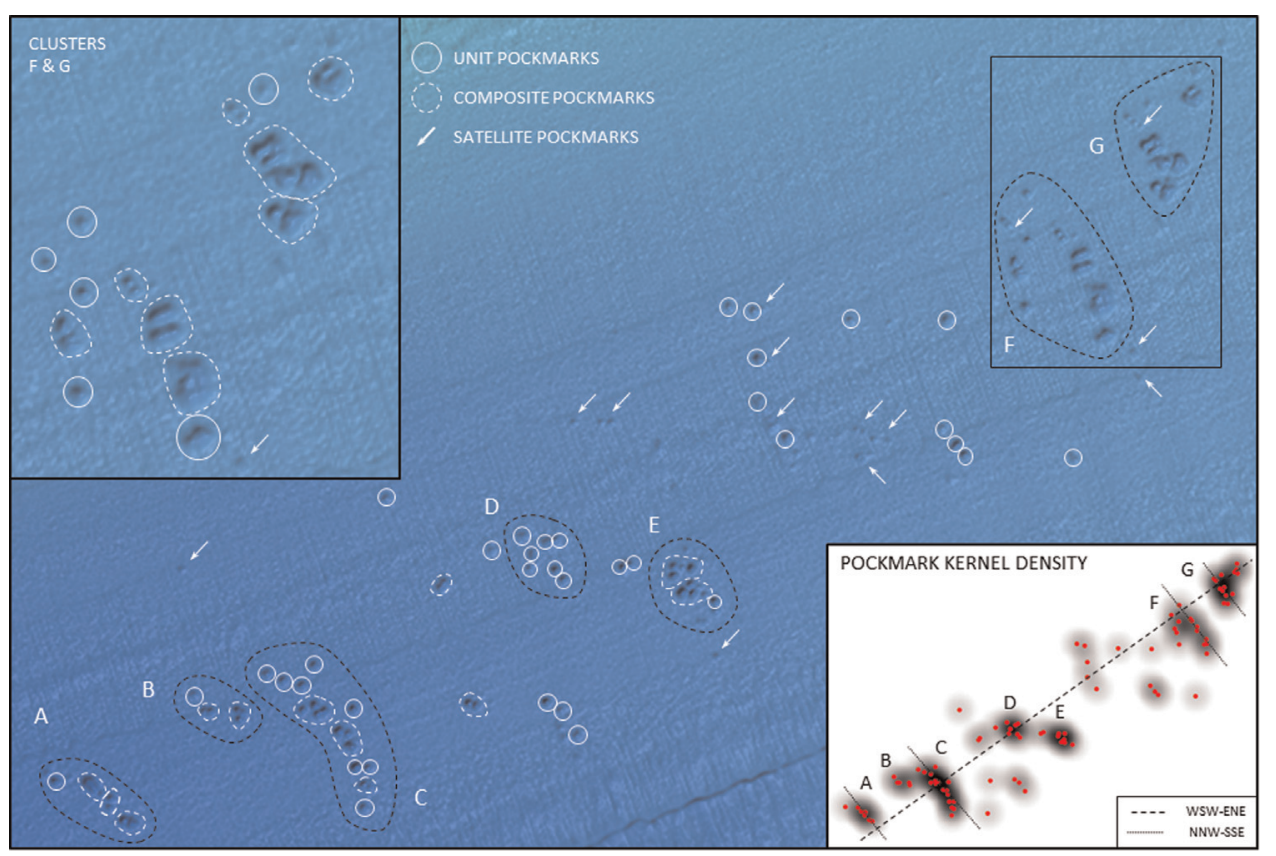

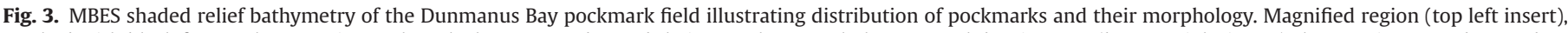

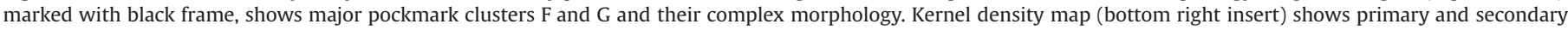
alignement of the field and the features respectively and illustrates the natural groupings of pockmarks into seven major clusters (DOUBLE COLUMN).

comprises 5 subunits and reaches $15 \mathrm{~m}$ in its widest point. However, the majority of these features are very small in comparison to other pockmarks reported in the literature (Judd and Hovland, 2007). The width and length of the pockmark units range between 5.0 and $14.0 \mathrm{~m}$ and between 4.5 and $17.0 \mathrm{~m}$ respectively, averaging $8.1 \mathrm{~m}$ and $8.5 \mathrm{~m}$ respectively (Fig. 2). These are also very shallow features with the vertical relief ranging from 0.2 to $0.7 \mathrm{~m}$ and an average of $0.4 \pm 0.1 \mathrm{~m}$. There is also a group $(n=25)$ of very small (1-3 $\mathrm{m})$ and very shallow $(<0.2 \mathrm{~m}$ ) satellite pockmarks scattered across the field (Fig. 3). Part of these features $(n=11)$ occur in the vicinity of larger craters and might be related to the most recent fluid discharges as suggested by Hovland et al. (2010), but most of them are isolated $(n=14)$ and likely are remnants of small scale events possibly induced by subtle triggering mechanisms such as tidal pumping (Hovland et al., 2012). The perimeter of the Dunmanus Bay pockmarks areas vary between 34.6 and $88.9 \mathrm{~m}$ with an average of $52.3 \pm 12.5 \mathrm{~m}$. Most of these descriptors are negatively skewed towards lower values with the exception of a vertical relief which appears to be unimodal in distribution. Standard deviation of width and length ( 1.9 and $2.5 \mathrm{~m}$ respectively) implies more variability in the equatorial diameter which is most likely related to tidal and currents effects. These characteristics suggest that fluid release events occur frequently and on a small scale. Fine grained sediment seal thickness is probably the main controlling factor of pockmark sizes in Dunmanus Bay as observed in other, similar settings (e.g. Andrews et al., 2010). Thin, unconsolidated sediment layer and to smaller extent, low hydrostatic pressure, effectively lowers the overburden pressure threshold and thus favour frequent and low-magnitude venting events which in turn result in formation of small, clustered craters rather than large, isolated ones.

The average pockmark surface area is $225.0 \mathrm{~m}^{2}$ and ranges from 94.3 to $612.3 \mathrm{~m}^{2}$. The surface area standard deviation is quite high $\left(115.6 \mathrm{~m}^{2}\right)$ and implies a broad, but strongly negatively skewed, distribution of pockmark sizes. The cumulative surface area of pockmark scarred seabed is $21,595 \mathrm{~m}^{2}$ which represents $5.4 \%$ of the study area delineated by the acoustic data. This is in keeping with the findings of other authors, where the percentage of scarred seabed is typically reported as ranging from $1 \%$ to $10 \%$ of the total area (i.e. Dandapath et al., 2010, Gontz, 2002 and Hovland et al. 1984). However, in settings where favourable conditions occur, pockmark density might be much higher and represent as much as $24 \%$ of the seabed as reported by Andrews et al. (2010). The volume of pockmarks (calculated as half-spheroids) ranges from 1.3 to $27.1 \mathrm{~m}^{3}$ with an average of $8.0 \mathrm{~m}^{3}$ and represents a total of $767.5 \mathrm{~m}^{3}$ sediment displaced during their formation. This equates to an approximate volume of $19 \times 10^{2} \mathrm{~m}^{3} \mathrm{~km}^{-1}$ of affected seabed and indicates rather small scale events in comparison to sites where more vigorous venting takes place and where large volumes of sediment are displaced, for example in the Nile Deep Sea Fan region where approximately $11,300 \mathrm{~m}^{3} \mathrm{~km}^{-1}$ has been excavated (Moss et al., 2012). However, in settings with slow, diffuse fluid migration, such as the northern Californian margin, the amount of sediments moved can be considerably lower and reach volumes of $314 \mathrm{~m}^{3} \mathrm{~km}^{-1}$ (Yun et al., 1999). This might suggest that the Dunmanus Bay field, despite its modest size, is or has been experiencing low to moderate fluid flux through the seabed.

The majority of Dunmanus Bay pockmarks have aspect ratios typical for circular features $(L / W=1.0-1.5,44 \%)$; only a few can be classified as elliptical $(L / W=1.5-2.5,7 \%)$. There are a considerable number of pockmarks within the group with a circular characteristic which are differently orientated to the majority $(L /$ $W=0.8-0.9,25 \%)$. This suggests that seabed physical characteristics are the primary controlling factor for the shape of these pockmarks rather than the cumulative effects of tidal and current actions. The cross-sections of pockmarks varied between ' $\mathrm{V}$ 'shaped and ' $U$ '-shaped profiles, with the latter being naturally more common among the larger features. The sidewall slopes vary from $0.7^{\circ}$ in some composite features to $12.8^{\circ}$ in some isolated craters. The average slope is $6.4^{\circ}$ but the standard deviations of equatorial and polar sidewall slopes ranging from 2.2 to $2.6^{\circ} \mathrm{im}-$ ply some variability across the feature population (Fig. 2).

The Dunmanus Bay pockmark field shows clear WSW-ENE orientation and appears to be limited by two rock outcrops to the WSW and ENE. Individual pockmarks however, show a tendency 


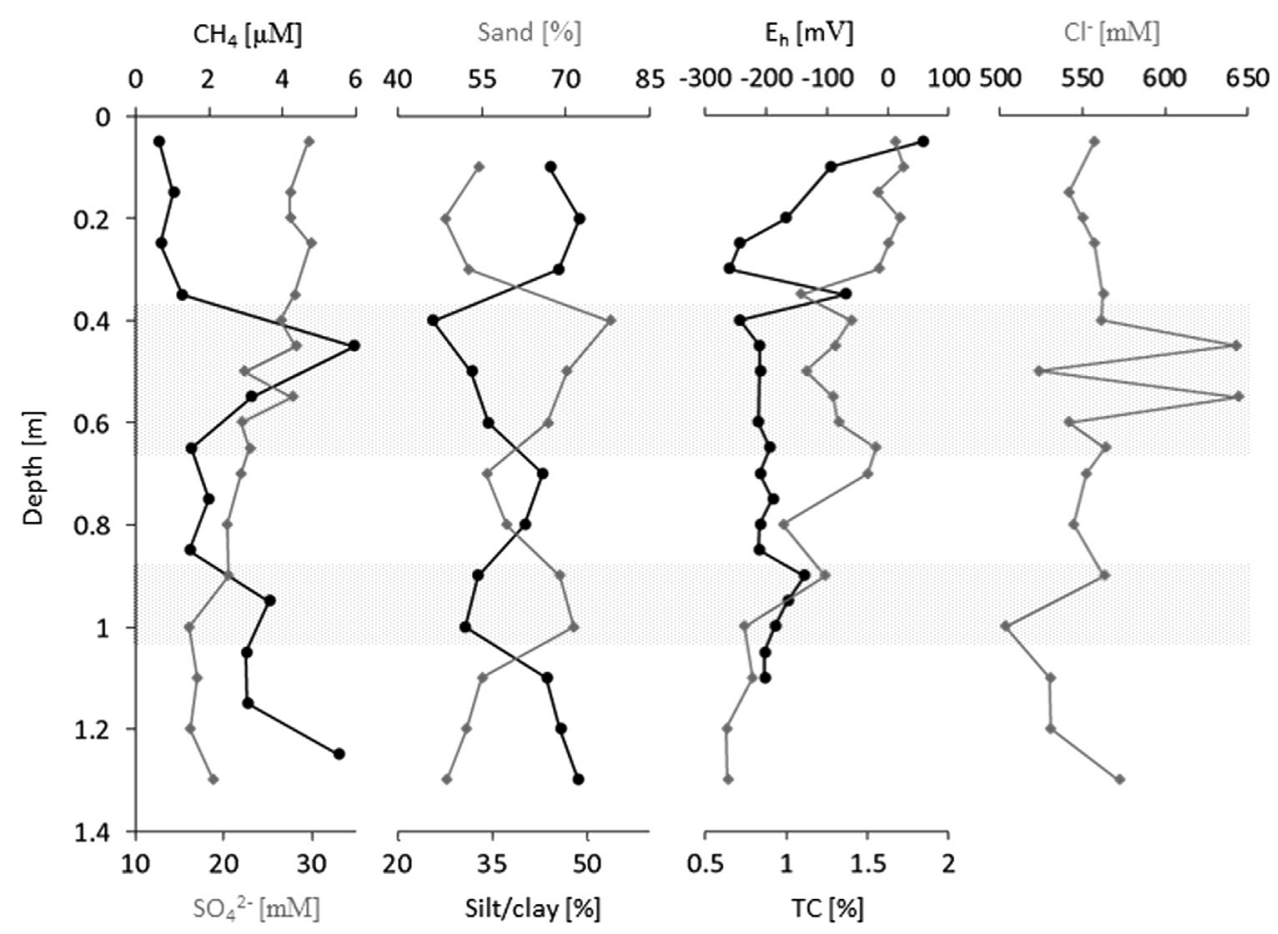

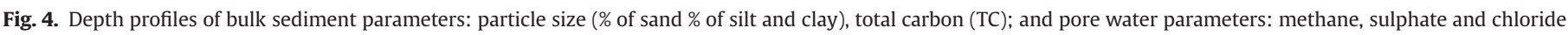

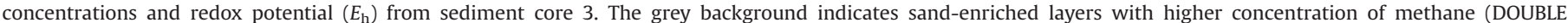
COLUMN).

to occur in clusters that appear to have a NNW-SSE orientation, which is particularly visible when considering only the major groupings. Kernel density analysis identified seven such clusters showing a varying degree of grouping (Fig. 3). The majority of pockmarks occur in these parallel clusters and only 24 individual units are observed outside of these pockmark groupings. The exact reason for the field orientation remains unclear as sub bottom data shows that the superficial sediments are predominately homogenous in structure and deep seismic data is not available. Pilcher and Argent (2007) demonstrated that on a larger, scale pockmarks can follow fault lines and form organised structures. It is therefore possible that the orientation of the field is related to the proximal Dunmanus Fault that is axially correlated with the field (Fig. 1). However, the orientation of individual clusters, due to their small size, is more likely related to shallow stratigraphy rather than deep structural features. Shallow sediment core analysis identified permeable, sand enriched strata, which could act as sub-surface conduits and channel the fluid to the surface as well as horizontally distribute it on a local scale (Fig. 4). The density of pockmark features suggest that these conduits are most likely reused and formation of new features should be expected in the vicinity of pre-existing clusters.

\subsection{Pockmark formation}

Pockmarks are features associated with fluid expulsion through the sediment. The fluid involved in the formation of most marine pockmarks is hydrocarbon gas, especially when associated with areas not adjacent to a landmass and therefore devoid of any aquifer influence (Judd and Hovland, 2007). Nevertheless, exceptions to this have been reported. In areas of the Florida Escarpment, part of the Florida Platform, freshwater seepages occur at depths exceeding $3000 \mathrm{~m}$ (Paull et al., 1984). Another example is Blake Ridge, located ca. $200 \mathrm{~km}$ offshore at $500 \mathrm{~m}$ depth (see Taniguchi et al., 2002 for review). However, in general, for estuarine, lacustrine and coastal settings, groundwater escape is a probable mechanism for pockmark formation. Pockmarks formed by this mechanism have been widely reported (e.g. Christodoulou et al., 2003; Khandriche and Werner, 1995). Since the Dunmanus Bay pockmarks are located just $650 \mathrm{~m}$ away from the landmass, freshwater expulsion is a potential formation mechanism for these features.

There was no evidence of salinity changes similar to those reported by Christodoulou et al. (2003) and others that would imply active flow of freshwater into the water column in Dunmanus Bay. The salinity in the lowermost $10 \mathrm{~m}$ of the water column shows a gradually increasing trend downwards at all stations, with an average value of 35.07 at the seabed. However, due to weather conditions, the CTD carousel had to be kept approximately $5 \mathrm{~m}$ above the seabed to compensate for the swell induced rocking of the vessel and to protect the instrument from contacting the seabed. This limitation was significant as the salinity decrease reported by Christodoulou et al. (2003) was observed only in the $3 \mathrm{~m}$ above the seabed while the water column above was not affected. It is therefore possible that moderate freshwater flow exists but was not detected as a result of survey conditions and instrument limitations. Detailed video surveying of these pockmarks with a fly-by camera during a recent research cruise (2011 CE11_017) did not reveal any visible freshwater flow (Shane O'Reilly, personal communication, May 20, 2011). However, this finding does not preclude the possibility of freshwater expulsion which can occur episodically. The west coast of Ireland historically experiences high levels of precipitation and so does Dunmanus Bay. The 30-year average of annual rainfall means (Walsh, 2012) is varying between 1400 and $1600 \mathrm{~mm}$ /year in this area and is above the national average $(1230 \mathrm{~mm} /$ year$)$. Moreover, vegetation is limited, often in the form of regulated farmland, and higher plants are virtually absent, thus water absorption is limited. Additionally, permeable rocks such as sandstone and limestone are the dominant rock types in the area (Naylor, 1975). According to Burnett et al. (2003) the above, along with groundwater abstraction and topography, are the main factors controlling the likelihood of a 


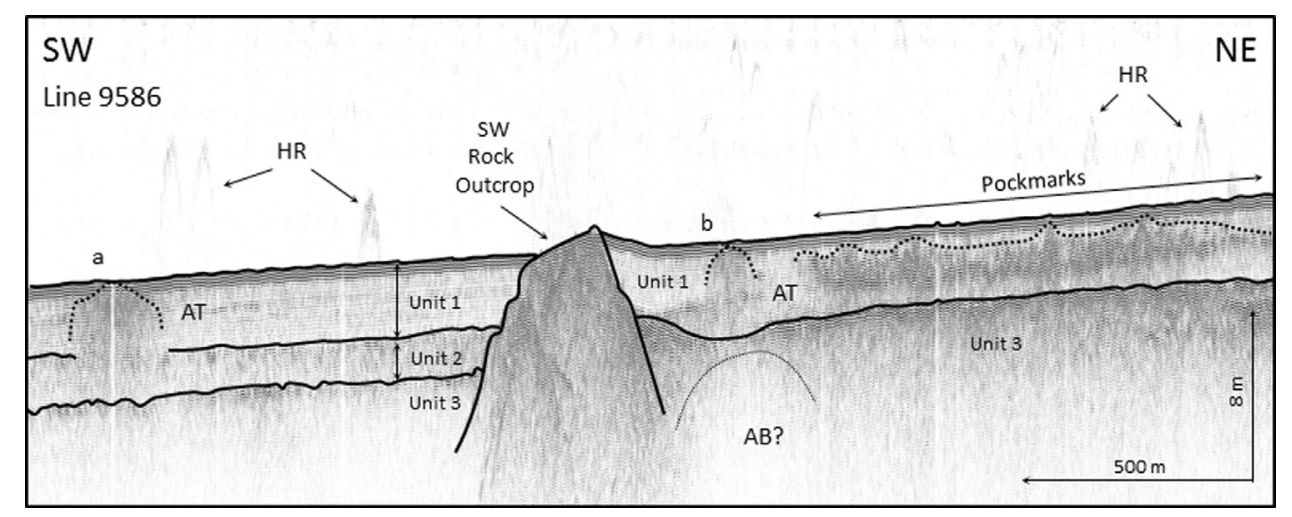

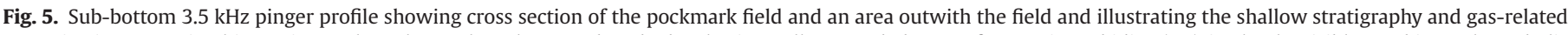

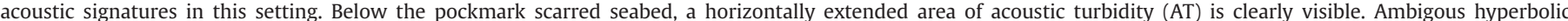

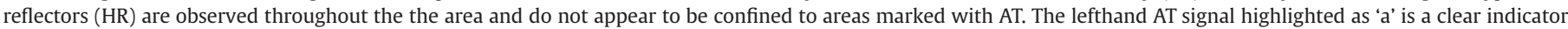

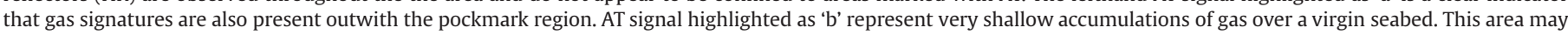

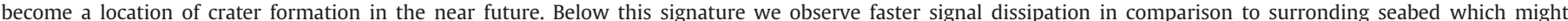
attributed to weak, gas related acoustic blanking (AB) (DOUBLE COLUMN).

groundwater discharge in a coastal setting. Given the above, it might be expected that, episodically, particularly after heavy rainfall, the amount of freshwater in unconfined aquifers would increase producing a pressure gradient that could result in pore fluid displacement and/or freshwater expulsion. Additionally, Wilson and Rocha (2012) identified water temperature anomalies, typically associated with submarine ground water discharge, just $1 \mathrm{~km} \mathrm{SW}$ from the studied pockmark field. This hypothesis is not, however, supported by the pore fluid data from the collected sediment core, though profiles show some interesting features (Fig. 4). The concentrations of chloride throughout the core show typical seawater values with no evidence of pore water freshening which would be expected if ground water was migrating through the seabed. Similarly, a reduction of sulphate is observed without any evidence of freshwater dilution. The sulphate profiles show an initial decrease and then at approx. $1.5 \mathrm{mbsf}$ the trend is reversed, possibly by re-oxidation of sulphate. A sharp decrease would be expected in the case of intrusion and for a diffusive/advective scenario, a linear or concave profile would be expected (Hensen et al., 2003). Therefore, we find no evidence of pore water freshening of either the water column or the sediment and conclude that freshwater expulsion is not a likely mechanism for the formation of Dunmanus Bay pockmarks.

Since freshwater is unlikely to be involved in the formation of these features hydrocarbon gas may be responsible. The acoustic data contains multiple signals that are commonly interpreted as associated with shallow gas and gas venting into the water column (Fig. 5). Numerous and extensive areas of acoustic turbidity (AT) as well as hyperbolic reflectors (HR) in the water column in the vicinity of the AT are clearly visible. AT is a strong indicator of shallow gas accumulation and is frequently reported in similar settings where seeps and pockmarks are observed (e.g. Ferrin et al., 2003). The AT appears to extend over a relatively wide area and is confined to the uppermost sedimentary unit which contains permeable sandy bodies. Moreover, acoustic blanking ( $A B)$ typically observed below the gas front is virtually absent in this setting. An important feature of these seismic profiles is the lack of AB signals directly below the prominent AT area which are frequently observed in upward migration scenarios (e.g. Szpak et al., 2012). Only one faint amplitude decrease was observed below one of the pockmarks that could be ascribed to $A B$, however, signal starvation is equally possible for this feature (Fig. 5). Therefore, an alternative, lateral migration scenario is more plausible in this setting. Assuming that gas is continuously being vented from a deeper source, namely bedrock fault, signals such as AB or AT connecting with the bedrock are to be expected. Such signals are not observed in this setting. However, this is only true for a continuous gas supply scenario. Periodic gas migration caused by successive cycles of seal failure-renewal is a viable hypothesis, particularly, given the vicinity of Gortavallig and Dunmanus Faults. AT signatures are observed also outside of the pockmark field and throughout the Dunmanus Bay but there are no surface gas expulsion features accompanying them. The prominent AT observed in the sub bottom profile located SW of the rock outcropping extends to the surface of the seabed and yet there are no pockmarks in this location (Fig. 5). This phenomenon can be attributed to changes in sediment type, as reflected in the coarser particle size distribution (Monteys et al., 2010). Pockmarks are generally formed in the fine-grained substrates since only these can provide the specific conditions needed for fluid over-pressurisation and subsequent forceful escape through the seabed upon seal failure. In Dunmanus Bay, medium to coarse sands dominate, including the south-western region shown in the sub-bottom profile (Fig. 5) included, and thus optimal conditions for pockmark formation are not abundant in this setting (Monteys et al., 2010).

The hyperbolic acoustic signals in the water column (HR) are ambiguous as fish swim bladders can produce similar features, though shape and migration patterns can help distinguish between them. Fish shoals, according to Judd et al. (1997), are more diffuse and horizontally extended, whereas, seeping gas will have more columnar, vertically extended characteristics. The shape of hyperbolic reflectors observed in the sub-bottom data (Fig. 5) is both horizontally and vertically extended and thus difficult to interpret. However, the MBES data also contains very narrow and vertical signals that are most likely caused by ascending bubbles (Fig. 6). As bubble diameter is directly related to its acoustic resonance frequency (Minnaert resonance) and selective visualisation of bubbles in data sets collected by instruments using different operational frequencies is not uncommon. Low frequency instruments, such as pinger, favour penetration rather than resolution unlike higher frequency instruments such as MBES which have narrow beam widths and are thus more suited for detection of gas plumes (Devaud et al., 2008). These signals do not appear to be artefacts since they occur in many locations (not all of such signatures are shown in Fig. 6) and more significantly the same vertical signals are observed in adjacent survey lines from the same seabed area. We therefore propose, given the acoustic data and the lack of evidence for water freshening from groundwater discharge, a venting mechanism based on successive cycles of seal failure-renewal as the probable formation mechanism for these pockmarks. 


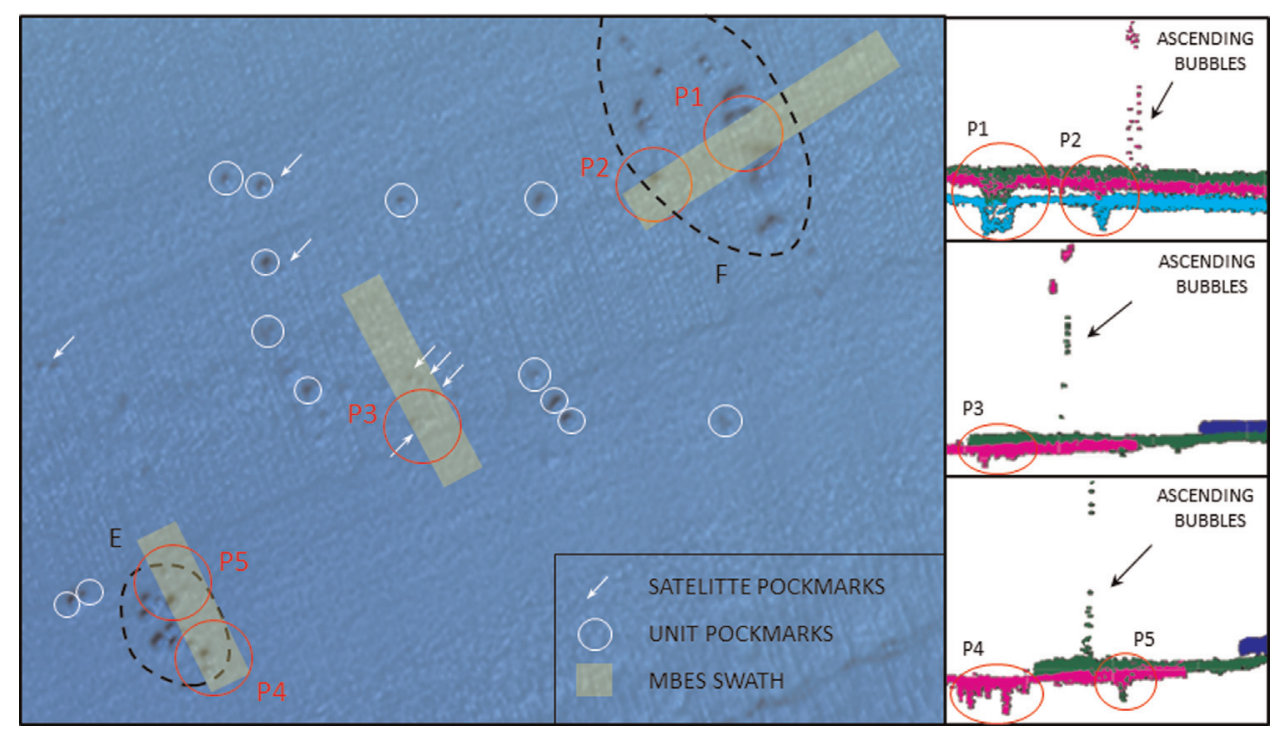

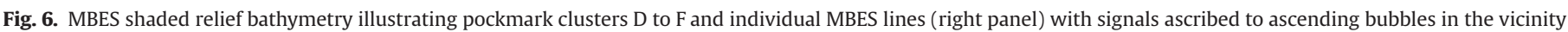
of the encircled pockmark features. Shaded areas represents MBES swath for reference (DOUBLE COLUMN).

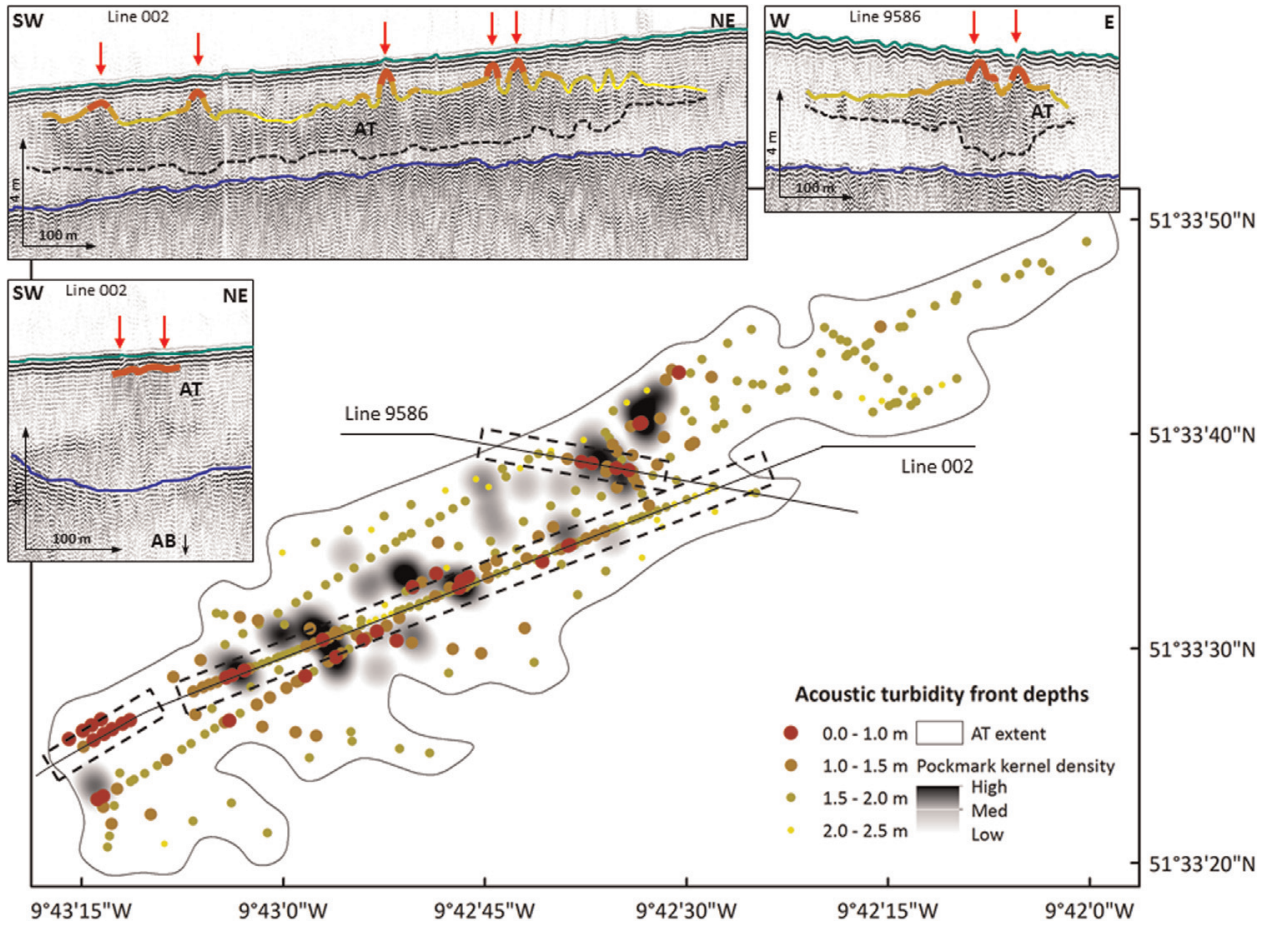

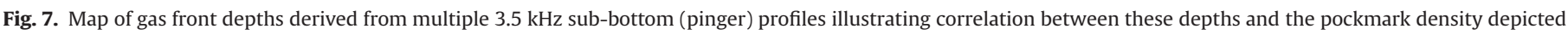

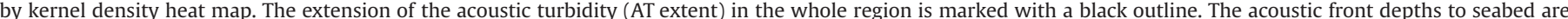

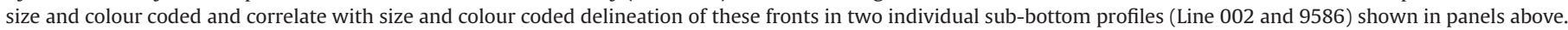
The areas corresponding to these sub-bottom profiles are marked wish dashed black line (DOUBLE COLUMN).

Hovland et al. (2010) suggests that small, satellite features accompanying larger pockmarks may be indicators of the most recent fluid escape events. The MBES data presented here (Fig. 6) only partially supports this hypothesis. Although, we observe gas bubbles in the areas where pockmark density was low and the majority of features are very small, we also observed flares in the vicinity of larger pockmarks. Moreover, after examining more subbottom profiles, we see that AT fronts are correlated with both pockmark density and gas front depths (Fig. 7). It is clear from this data that the shallower the gas front, the greater the number of pockmarks on the surface. This implies that, contrary to the Hovland hypothesis, the most active fluid systems are not located in the vicinity of smaller features in this setting. The moderate positive correlation $\left(R^{2}=0.41, n=435\right)$ between the thickness of the gas front and its depth from the sediment water interface suggests the existence of pathways through which the gas is channelled through the seabed. It has been reported that AT front depth might show seasonal variability caused primarily by seasonal temperature fluctuations of bottom waters (Hagen and Vogt, 1999). In Dunmanus Bay however, such fluctuation will be minimal as these waters are well stratified throughout the year and seasonal temperature variability is on the order of $\pm 5^{\circ} \mathrm{C}$ (O'Sullivan et al., 2014) as derived from Regional Ocean Modelling System (ROMS). 


\subsection{Estimation of methane in the subsurface and flux rates}

The surface area of the gas charged sediments derived from extension of the AT observed in the sub bottom data sets (Fig. 5 and 7) covers an area of only $0.4 \mathrm{~km}^{2}$. The thickness of the gas charged sediments estimated from sub-bottom data varies from 0.2 to $5.7 \mathrm{~m}$ with an average of $1.9 \mathrm{~m}$ ( $\pm 1.0 \mathrm{~m}, n=435)$. Thus, the total volume of gas charged sediments amounts to ca $754 \times 10^{3} \mathrm{~m}^{3}$, a relatively small figure compared with others reported from shallow settings (Hovland and Judd, 1992). In line with the evidence presented above, we propose that the shallow gas accumulations are primarily distributed within sand enriched and, thus, more permeable strata. Therefore, the highest recorded concentration of methane ( $96 \mathrm{ppb}$ ) within the sediment core is used for calculation of total methane trapped in the subsurface giving a conservative estimate of $0.72 \times 10^{6} \mathrm{~g}$ of methane present in the sub surface of the Dunmanus Bay pockmark field. For a more accurate distribution, more sediment samples should be analysed to: (i) verify the concentration of methane in acoustically distinguishable units, (ii) verify the composition of strata with prominent AT signatures, and (iii) to consider variability in the gas front thickness to represent more accurately the volume of the affected seabed.

Hovland and Judd (1992) reviewed many shallow gas accumulations globally and proposed three methane average flux estimates based on the physical evidence of ebullition: (i) $26 \mathrm{~g}$ $\mathrm{CH}_{4} \mathrm{~m}^{-2}$ year ${ }^{-1}$ for settings with visible ebullition, (ii) $13 \mathrm{~g}$ $\mathrm{CH}_{4} \mathrm{~m}^{-2}$ year $^{-1}$ for settings with intermittent ebullition, and (iii) $6 \mathrm{~g} \mathrm{CH}_{4} \mathrm{~m}^{-2}$ year $^{-1}$ for settings with no visible ebullition. Based on the evidence presented here, we suggest that Dunmanus Bay can be classified between scenarios (i) and (ii) yielding methane fluxes ranging between $2.4 \times 10^{6} \mathrm{~g} \mathrm{CH}_{4} \mathrm{~m}^{-2}$ year $^{-1}$ and $5.2 \times 10^{6} \mathrm{~g} \mathrm{CH}_{4} \mathrm{~m}^{-2}$ year $^{-1}$. Global annual methane flux from shallow settings to the water column (defined as areas $<250 \mathrm{~m}$ isobaths) is estimated at $1456 \times 10^{12} \mathrm{~g} \mathrm{CH}_{4}$. Dunmanus Bay, by comparison, contributes only between $1.6 \times 10^{-6}$ and $3.6 \times 10^{-6} \%$ o. We conclude, therefore, that Dunmanus Bay pockmarks are not an important source of methane on a wider scale.

\subsection{Pockmark activity}

Detection of active venting is rarely reported in the literature. However, climate change driven warming of the world's oceans may increase the discovery of active seepages in the near future (Skarke et al., 2014). According to current pockmark formation models (e.g. Cathles et al., 2010, Judd and Hovland, 2007), periodic gas expulsion, particularly after initial violent pockmark formation, is typical for most pockmarks and they are considered settings where moderate fluid migration is dominant. Nevertheless, active venting has been reported. Kelley et al. (1994) reported active venting in post-glacial sediments in Belfast Bay, US. Newman et al. (2008) demonstrated methane concentrations reaching $100 \mathrm{nM}$ in pockmarks along the US mid-Atlantic shelf break. Christodoulou et al. (2003) reported both freshwater and gas related active pockmarks systems in the Patras and Corinth gulfs, Greece. In both of these studies the METS sensor (Garcia and Masson, 2004) was used to measure methane concentrations in the water column above and in the vicinity of pockmarks. We have employed the same instrument in Dunmanus Bay and observed that bottom (ca. $5 \mathrm{~m}$ above seabed) methane concentrations along the $\mathrm{W}$ to $\mathrm{E}$ transect (Fig. 1) ranged from 5.1 to $14.2 \mathrm{nM}$ with an average of $9.5 \mathrm{nM}$. Slightly higher values were consistently recorded in the western part of the pockmark field, however, overall variability of the data is low and the highest concentrations only slightly exceed typical marine water methane values (Holmes et al., 2000). Although acoustic evidence of gas bubbles in the

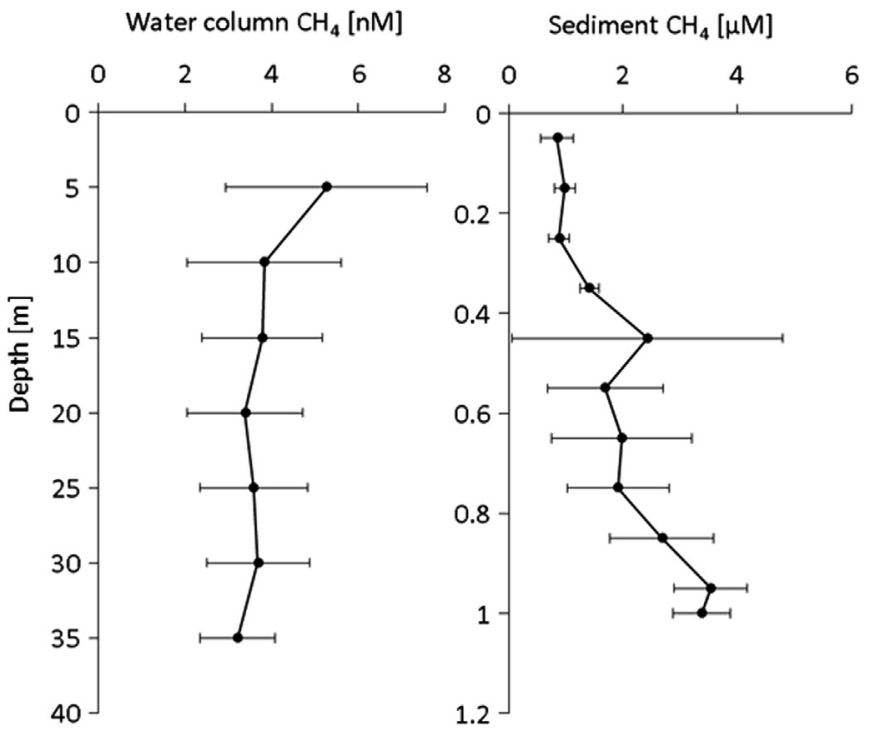

Fig. 8. Average concentration profiles of methane in the water column (casts 3, 8, 14 and 15) and sediment cores (cores 3, 4, 9 and 10). Error bars represent standard deviations between individual profiles. Note that largest variations in sediment cores are observed at the same depths as the sand-enriched layers (refer Fig. 4) (SINGLE COLUMN).

water column was acquired, the methane concentrations in the water column were not significantly elevated. Discrete samples collected across the water column show similar concentrations which ranged from 2.2 to $7.7 \mathrm{nM}$ resulting in very similar concentration profiles (Fig. 8).

Although methane concentrations in the water column were low, despite acoustic evidence of seepage, this is not uncommon in other areas where shallow gas accumulation is observed along with evidence of vigorous venting. Dando et al. (1991) reported methane concentrations from a large active pockmark in the North Sea with only two of six stations exceeding $25 \mathrm{nM}$. For half of these, methane was below $15 \mathrm{nM}$. They found higher concentrations exceeding $50 \mathrm{nM}$ only in areas where an echo sounder showed strong signals from gas bubbles in the water column. It is therefore possible that the gas dissipated into the water column and/or the magnitude of the seepage was so low that it was not captured during sampling. This suggests discreet and periodic seepage rather than continuous and that a more targeted approach, with use of instrumentation that can cover a large area and is quick to deploy, would be more appropriate. The bottom water methane concentrations recorded by the METS sensor were slightly higher than those from the head-space analysis but overall they are in good agreement. A gradual decrease in concentrations along the $\mathrm{W}-\mathrm{E}$ transect was observed $\left(R^{2}=0.73\right)$. The highest $\mathrm{CH}_{4}$ concentrations $(14.2,12.2$ and $13.3 \mathrm{nM}$,) were recorded for the first three stations (03, 01 and 02 respectively) followed by a drop to very low values ranging from 5.1 to $6.6 \mathrm{nM}$ (stations 32 and 13, respectively).

The concentration of methane in the sediment cores (Figs. 4 and 8) shows a general increasing trend with depth. The values range from $<1.0$ to $6 \mu \mathrm{M}$ in the deeper sections. Higher hydrocarbons $C_{2+}$ (mostly $C_{2}$ ) were present in trace amounts. Therefore, the gas can be considered dry and the lack of higher homologues implies microbial origin (Faber and Stahl, 1984; Floodgate and Judd, 1992). In a normal setting where shallow gas is absent, methane generation is only possible after sulphate has been depleted and methane is not present in the sediment above the sulphate depletion depth (Hensen et al., 2003). The sulphate is far from depleted yet methane presence was detected through the entire sediment core. This suggests that the methane is migrating 
upward from the AT area observed in the sub-bottom profile (Fig. 5). The in situ generation of methane in the uppermost sediments is a possible contributor to the overall methane pool accumulated in these sediments; however, based on pore water and sediment composition, it is likely to be limited. The optimal conditions in the sediment for methanogens to thrive are: (i) a lack of oxygen, since all known methanogens are strict anaerobes, (ii) sufficient amounts of biologically available organic carbon, typically more than $0.5 \%(\mathrm{w} / \mathrm{w})$, and (iii) sulphate depletion for competitively centred metabolisms. Nevertheless, methanogens are known to effectively utilise the availability of non-competitive substrates such as methanol and methylamines and thus produce methane even in the outlined geochemical setting (King et al., 1983). The redox potential measurements suggest that conditions in the sediment are indeed anoxic (Fig. 4), though the sediment was not fully reduced (black). This is an interesting finding given that a low redox potential $(<150 \mathrm{mV}$ ) marking the beginning of the anoxic zone is usually, however not always, coupled with depletion of sulphate which we did not observe. Nevertheless, given that sulphate is not depleted, the microbial generation of methane is probably limited.

Dunmanus Bay pockmarks are clearly features created by gas expulsion. The acoustic data confirms the presence of shallow, lateral gas accumulation and bubbles in the water column. However, the water column sampling did not provide sufficient evidence that these bubbles are methane gas. Judging from the pockmark size and the acoustic signals in the subsurface, gas venting may be moderate in nature. The pockmarks are relatively small and they are accompanied by scattered, small satellite features which appear to be remnants of past activity rather than the result of recent and active local seepage as suggested by Hovland et al. (2010). Methane concentrations in the water column measured on discrete samples (Figs. 4 and 8) and by the METS sensor show no evidence of the drastically elevated methane concentrations typically observed in sites where vigorous venting takes place.

\subsection{Pockmarks and benthic communities}

The variety and abundance of marine life associated with seepages can be remarkable across all trophic levels. Dynamic, energetic venting systems are known to support unique ecosystems (see Kiel, 2010 for a review). There is evidence that pockmarks on a smaller scale can support local communities, however, the debate continues (Judd and Hovland, 2007). To examine if local communities from Dunmanus Bay are affected by these features a benthic survey was conducted over the pockmark area (Fig. 1).

Benthic infauna from 10 grab sampling stations within Dunmanus Bay yielded 8865 individuals, which were identified to 122 species across 12 phyla (Station 16 - control; Stations 17 to 41 experimental). The majority of these species were polychaete worms (57 species), with crustaceans (25), molluscs (13) and echinoderms (8) also well represented. Between stations, the number of individuals recorded from each station always exceeded 382 , with a maximum of 1878 individuals, but abundance is not correlated to the number of species (Pearson correlation $r=0.179$, $p=0.62$ ). See Table 3 for summary of diversity indices.

Four species dominate the assemblages at most stations - the echinoderms Leptopentacta elongata (Cucumariidae, Duben and Koren) and Amphiura filiformis (Amphiuridae, Muller) and the polychaetes Diplocirrus glaucus (Terebellida, Malmgren) and Scalibregma inflatum (Annelida, Rathke) - accounting for 5-17\% of the species at each station and $75-92 \%$ of the individuals. A. filiformis and $D$. glaucus are correlated together (Pearson $r=0.721, p=0.019$ ), both preferring higher silt-clay locations (NS), as were L. elongata and $S$. inflatum $(r=0.571, p=0.085)$. Although non-significant
Table 3

Diversity indices calculated for each biological station in the Dunmanus Bay. Individuals are total counts from five replicates.

\begin{tabular}{|c|c|c|c|c|c|c|}
\hline ID & Lat & Long & Type & Analysis & Depth [m] & $\begin{array}{l}\text { AT depth } \\
\text { [mbsf] }\end{array}$ \\
\hline 39 & 51.5603 & -9.7099 & Day grab & $\begin{array}{l}\text { PSA, } \\
\text { Benthos }\end{array}$ & 42.2 & $0.0-2.0$ \\
\hline 22 & 51.5605 & -9.7105 & Day grab & $\begin{array}{l}\text { PSA, } \\
\text { Benthos }\end{array}$ & 42.3 & $0.0-2.0$ \\
\hline 21 & 51.5603 & -9.7114 & Day grab & $\begin{array}{l}\text { PSA, } \\
\text { Benthos }\end{array}$ & 42.4 & $1.5-2.0$ \\
\hline 20 & 51.5587 & -9.7137 & Day grab & $\begin{array}{l}\text { PSA, } \\
\text { Benthos }\end{array}$ & 43.1 & $0.0-2.0$ \\
\hline 19 & 51.5587 & -9.7146 & Day grab & $\begin{array}{l}\text { PSA, } \\
\text { Benthos }\end{array}$ & 43.3 & $0.0-2.5$ \\
\hline 18 & 51.5582 & -9.7170 & Day grab & $\begin{array}{l}\text { PSA, } \\
\text { Benthos }\end{array}$ & 43.7 & $1.5-2.0$ \\
\hline 17 & 51.5575 & -9.7169 & Day grab & $\begin{array}{l}\text { PSA, } \\
\text { Benthos }\end{array}$ & 43.9 & $1.0-1.5$ \\
\hline 16 & 51.5574 & -9.7104 & Day grab & $\begin{array}{l}\text { PSA, } \\
\text { Benthos }\end{array}$ & 42.7 & Control \\
\hline 40 & 51.5613 & -9.7096 & Day grab & $\begin{array}{l}\text { PSA, } \\
\text { Benthos }\end{array}$ & 42.1 & $0.0-2.5$ \\
\hline 41 & 51.5576 & -9.7157 & Day grab & $\begin{array}{l}\text { PSA, } \\
\text { Benthos }\end{array}$ & 43.7 & $0.0-2.0$ \\
\hline 21 & 51.5604 & -9.7119 & SPI & SPI analysis & 42.5 & $1.5-2.5$ \\
\hline 16 & 51.5576 & -9.7100 & SPI & SPI analysis & 42.6 & Control \\
\hline 39 & 51.5600 & -9.7098 & SPI & SPI analysis & 42.3 & $1.5-2.5$ \\
\hline 22 & 51.5606 & -9.7100 & SPI & SPI analysis & 42.9 & $0.0-1.0$ \\
\hline 40 & 51.5609 & -9.7100 & SPI & SPI analysis & 42.4 & $1.0-2.0$ \\
\hline 17 & 51.5574 & -9.7170 & SPI & SPI analysis & 44.0 & $1.0-1.5$ \\
\hline 18 & 51.5587 & -9.7170 & SPI & SPI analysis & 43.6 & $1.0-2.0$ \\
\hline 41 & 51.5579 & -9.7149 & SPI & SPI analysis & 43.6 & No data \\
\hline 19 & 51.5587 & -9.7138 & SPI & SPI analysis & 43.2 & $1.5-2.0$ \\
\hline 20 & 51.5590 & -9.7135 & SPI & SPI analysis & 43.2 & $0.0-2.0$ \\
\hline 3 & 51.5604 & -9.7111 & Gravity core & $\begin{array}{l}\text { PSA, TC, PW, } \\
\text { R, DM }\end{array}$ & 42.5 & $1.5-2.0$ \\
\hline 4 & 51.5605 & -9.7097 & Gravity core & $\mathrm{R}, \mathrm{DM}$ & 43.0 & $0.0-1.5$ \\
\hline 9 & 51.5581 & -9.7163 & Gravity core & $\mathrm{R}, \mathrm{DM}$ & 43.8 & $1.0-1.5$ \\
\hline 10 & 51.5585 & -9.7145 & Gravity core & $\mathrm{R}, \mathrm{DM}$ & 43.4 & $1.0-1.5$ \\
\hline 1 & 51.5570 & -9.7167 & Carousel WS & CTD, METS & 43.9 & Inside PF \\
\hline 2 & 51.5593 & -9.7157 & Carousel WS & CTD, METS & 43.3 & Inside PF \\
\hline 3 & 51.5593 & -9.7187 & Carousel WS & $\begin{array}{l}\text { CTD, METS, } \\
\text { DM }\end{array}$ & 43.5 & Outside PF \\
\hline 8 & 51.5593 & -9.7138 & Carousel WS & $\begin{array}{l}\text { CTD, METS, } \\
\text { DM }\end{array}$ & 43.1 & Inside PF \\
\hline 11 & 51.5593 & -9.7085 & Carousel WS & CTD, METS & 42.2 & Outside PF \\
\hline 12 & 51.5594 & -9.7078 & Carousel WS & CTD, METS & 42.0 & Outside PF \\
\hline 14 & 51.5593 & -9.7115 & Carousel WS & $\begin{array}{l}\text { CTD, METS, } \\
\text { DM }\end{array}$ & 42.7 & Inside PF \\
\hline 15 & 51.5593 & -9.7152 & Carousel WS & $\begin{array}{l}\text { CTD, METS, } \\
\text { DM }\end{array}$ & 43.2 & Inside PF \\
\hline 31 & 51.5594 & -9.7103 & Carousel WS & CTD, METS & 42.4 & Inside PF \\
\hline 32 & 51.5593 & -9.7070 & Carousel WS & CTD, METS & 41.8 & Outside PF \\
\hline 4 & 51.5602 & -9.7118 & Box core & PSA, R & 42.6 & No data \\
\hline 1 & 51.5590 & -9.7129 & Box core & PSA, $R$ & 43.7 & $0.0-1.0$ \\
\hline 3 & 51.5596 & -9.7123 & Box core & PSA, R & 42.8 & $1.5-2.0$ \\
\hline 15 & 51.5602 & -9.7097 & Box core & PSA, $\mathrm{R}$ & 42.2 & $1.0-1.5$ \\
\hline 33 & 51.5609 & -9.7094 & Box core & PSA, $R$ & 42.2 & $1.0-1.5$ \\
\hline 28 & 51.5613 & -9.7093 & Box core & PSA, R & 42.5 & $0.0-1.0$ \\
\hline 32 & 51.5615 & -9.7090 & Box core & PSA, $R$ & 41.8 & $2.0-2.5$ \\
\hline 11 & 51.5614 & -9.7095 & Box core & PSA, R & 42.0 & $2.0-2.5$ \\
\hline 6 & 51.5611 & -9.7105 & Box core & PSA, R & 42.0 & $2.0-2.5$ \\
\hline
\end{tabular}

trends, the data suggests we should expect strong correlations had a greater number of stations had been sampled. All four species are predominantly deposit feeders utilising the sediment surface to obtain prey, rather than burrowing through it.

Cluster analysis was performed to find the similarity between stations. A multi-dimensional scaling (MDS) plot (Fig. 9) show a low stress $(\sigma=0.05)$ value indicating a very good reproduction of the information contained in the distance matrix. Most experimental stations are $50-60 \%$ similar in terms of the species composition at these stations, with those spatially closer to each other 


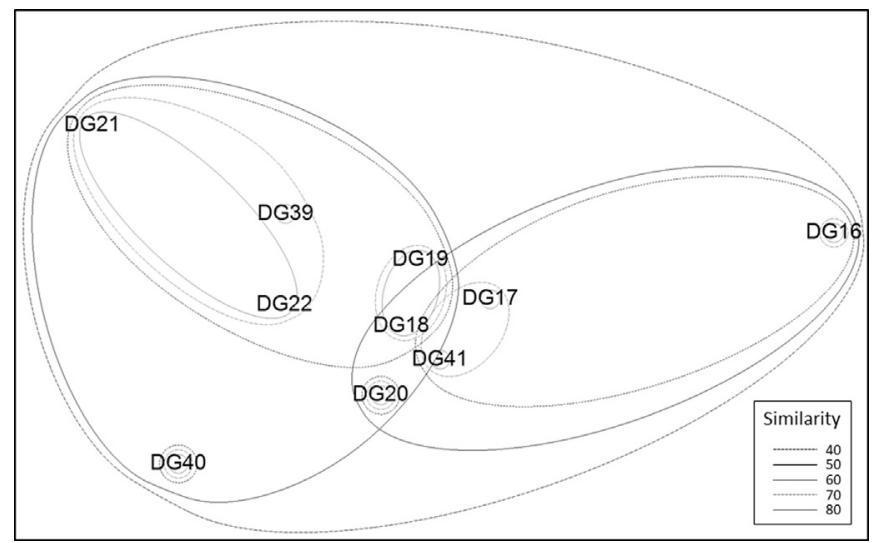

Fig. 9. MDS plot illustrating the degree of similarity between benthic communities in the Dunmanus Bay pockmark field. The reference station (16) is grouped outside of the other stations and shows moderate similarity with the more southerly statons. Stress is $\sigma=0.05$ (ONE and HALF COLUMN).

sharing more species, while the control station only shares a $40 \%$ similarity with all the experimental sites and 50-60\% with the southern stations. Removing the four dominant species reduced the similarity to $47-71 \%$ between experimental stations and $38 \%$ to the control, but did not change the overall patterns significantly.

Communities of polychaetes and echinoderms have previously been observed in a North Sea pockmark (Dando et al., 1991), though the species composition differs in that there are few Amphiura sp. This composition is not specific to pockmarked regions; Oslo fjord, for example, is also dominated by polychaetes and bivalve molluscs (Webb et al., 2009a), but this is more representative of the regional biota than pockmark. The polychaete and echinoderm mix of infauna in Dunmanus Bay is similar to Killary Harbour, also in the west of Ireland, (Keegan and Mercer, 1986), particularly with regard to the Amphiura brittle star community, though A. filiformis dominates A. chiajei in Dunmanus Bay. Depth stratification between the species is known with $A$. filiformis common above $70 \mathrm{~m}$ water depth (Buchanan, 1964). Scalibregma inflatum is also common in Killary Harbour, reaching high abundances where the organic carbon levels are greater than $8 \%$. This high organic biomass might be expected from the north-eastern stations given that $S$. inflatum is abundant here, and that such silty, high biomass conditions also benefit the Amphiura community (Rosenberg, 2001), but the source of this sediment is unknown given the lack of significant freshwater inputs. Interestingly, despite observing an Amphiura sp. community in Dunmanus Bay, no Echinocardium were observed though this species occurs frequently with A. filiformis (Buchanan, 1964).

The control site has the smallest proportion of the four dominant species as well as lower coarse sediments (1.6-3.8 $\times$ less coarse material) and higher fine sediment content than any of the experimental sites. Coarser sediments within pockmark centres may be the result of venting (Webb et al., 2009b), if sufficient gas is available to disturb the sediment structure. Equally, bottom currents might be responsible for the accumulation of coarser particles inside of pockmarks, particularly in settings with sufficient input of coarse material such as Dunmanus Bay (Pau and Hammer, 2013). Bottom currents, intermittent scouring or trawling will reduce the diversity of species, which may then take time to recolonise a region (Wildish et al., 2008). The control site also has 27 species unique to this station (22\% of the total count), including 12 polychaete species and five molluscs. Contrastingly 45 species, found elsewhere in the study, did not occur at the control site, though 36 of these species are represented by fewer than five individuals across the 9 sites and 28 of them on only one occasion, making their absence at station 16 likely a result of chance.
Sediment structure is likely to have dictated the species composition, as fine sediments tend to increase species diversity in benthic habitats (reviewed by Gray, 2002) and oxygen saturation can also dictate the community composition (Rosenberg, 2001). Mobile echinoderms (such as starfish, brittle stars and holothurians) appear to be common colonisers of pockmarked regions, but abundances within the pockmarks can be lower than surrounding regions (e.g. Wildish et al., 2008). Contrastingly, we observed higher abundances of these species within the pockmark area than in the control site, but this may be dictated by the limited amount of gaseous activity in Dunmanus Bay.

Profiles of the sediment water interface collected with the SPI camera show numerous burrows, mainly vertical but also lateral, voids, and in places infauna (Fig. 10). The images show a substrate of mainly very fine sand with a few patches of coarser sand. Progression of natural geochemical zonation is visible in most profiles in the form of discrete colour change delineating the extent of apparent redox potential discontinuity (aRPD). However, in most images the transition is not sharp (e.g. stations 16, 18, 20) and marked with characteristic dark streaks. This might be indicative of bioturbation and/or bioirrigation given the high count of actively burrowing species. Data from Rosenberg (2001) suggests that the discontinuity would be quite shallow in this area, due to the absence of larger burrowing species and a community dominated by polychaetes and Amphiura sp. Overall, the images are generally in good agreement with the redox potential profiles taken on undisturbed box and gravity cores (Fig. 11).

Oxygenated sediment (with typical values $>+200 \mathrm{mV}$ ) is present only in the very top few $\mathrm{cm}$ of the sediment. This part of the seabed comprised of photodetrital debris and loose sands, often referred to as 'drift', followed by a fine sand substrate. This was expected as the penetration of oxygen in marine sediments does not usually exceed a few $\mathrm{cm}$ and in areas with high particulate matter input from the water column, it can be as low as a few mm or even absent (Cai and Sayles, 1996). The post-oxic zone (with typical values from -150 to $+200 \mathrm{mV}$ ) ranges from a shallow $4 \mathrm{~cm}$ to more than $15 \mathrm{~cm}$ at most stations and, from the SPI profiles, it is clear that burrowing species greatly affect the homogeneity and extent of this zone. Fully anoxic conditions (typically $<-200 \mathrm{mV}$ ) are not reached in most stations, which is in concordance with redox and pore water data discussed in previous paragraphs. The only station with fully reduced sediment is station 22, which was located on top of a major pockmark cluster (see Fig. 1, and cluster F in Fig. 3). The aRPD in this profile reaches the sediment water interface but the natural succession is inverted, possibly due to increased infauna activity. Nevertheless, the post-oxic zone in this profile is virtually absent which indicates high organic matter loading. It is this loading which is likely to have dictated the community composition, unsurprisingly as depressions such as pockmarks often act as sinks for detrital matter leading to intensification of diagenetic processes and the rapid consumption of electron donors. However, a sufficiently high flux of methane can also push the redox boundaries towards the sediment water interface (Borowski et al., 1996). Therefore, the effect of rising methane gas cannot be out ruled.

Pockmarked environments can create niches for species with chemosymbiotic adaptions. Dando et al. (1991) identified two chemosymbiotic species from a pockmark in the North Sea. One of these genera, the bivalve mollusc Thyasira sp., was found in low abundances at St 20 and 40. This genus, is known to predominantly utilise sulphur-oxidising bacteria for obtaining nutrition, therefore, its presence may indicate the presence of gas seeps at these locations (Dando et al., 1991, Webb et al., 2009a, Wildish et al., 2008). It must be noted, however, that this genus also occurs in organic-rich sediments (Dando et al., 1991) and may also explain its presence in Dunmanus Bay. Other species known to 


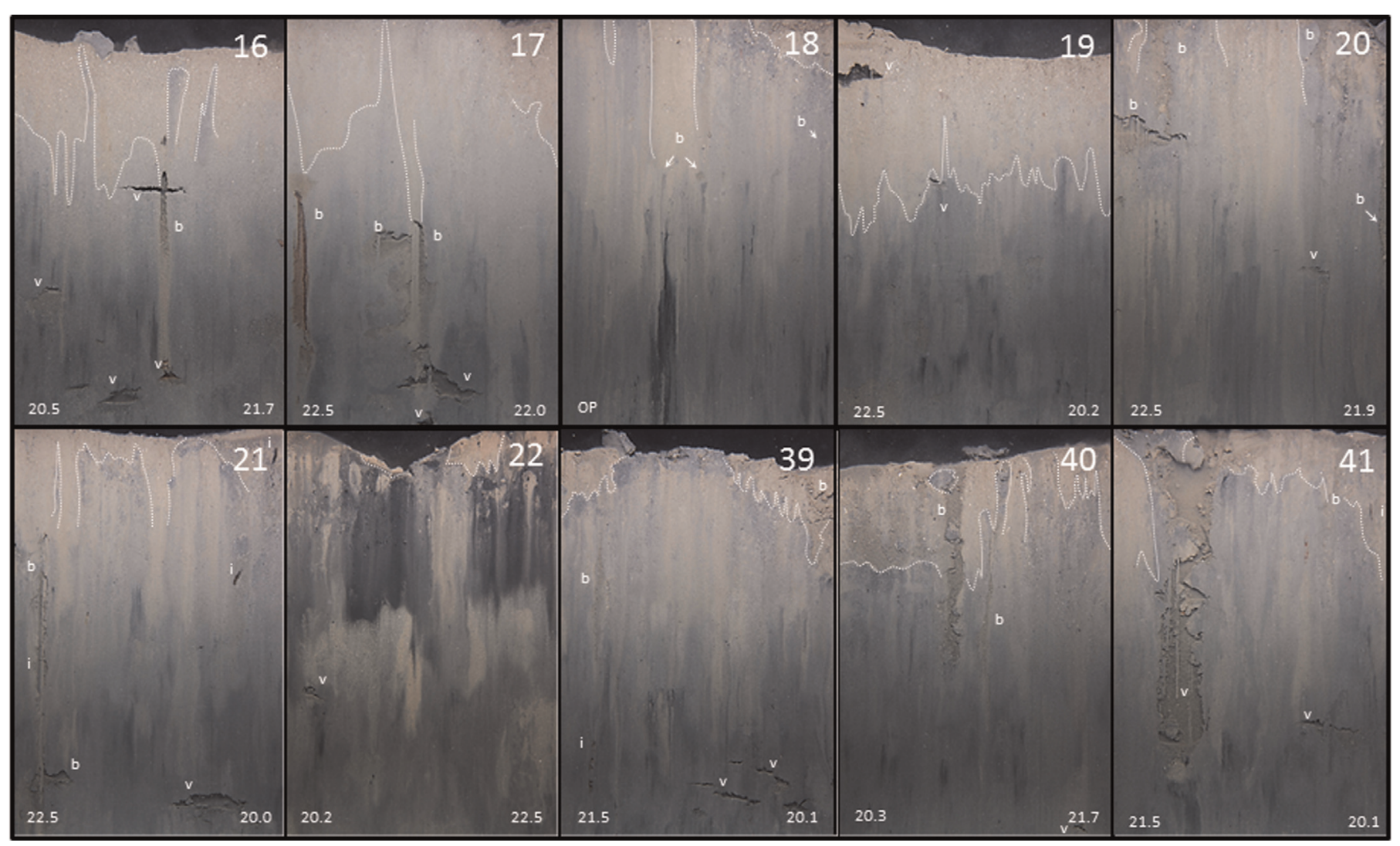

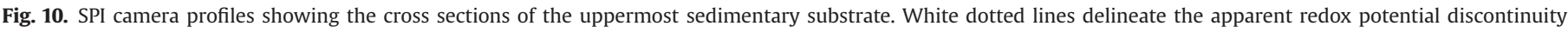

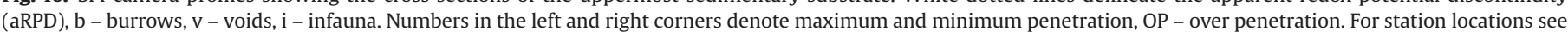
Fig. 1 (DOUBLE COLUMN).

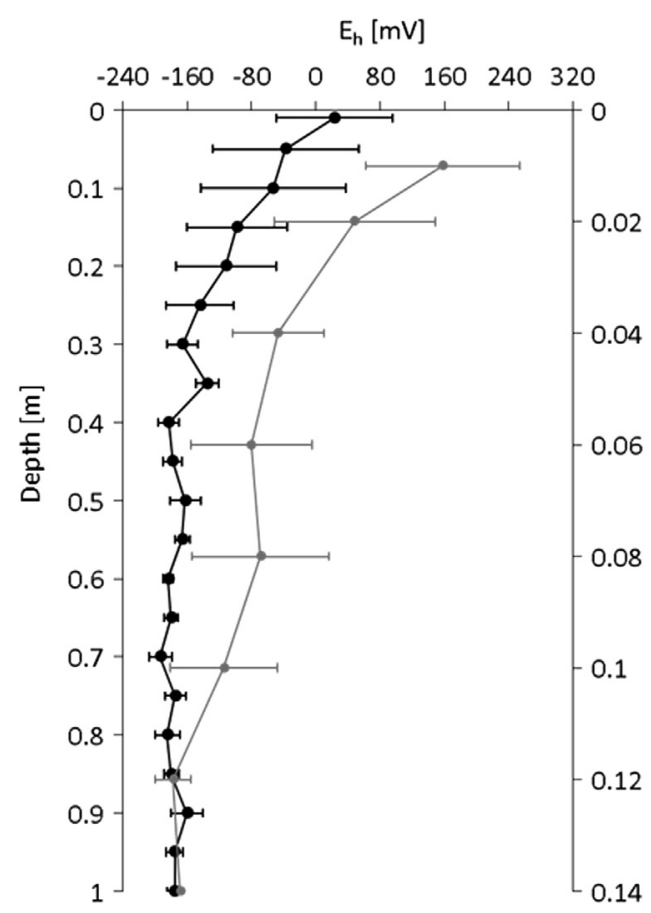

Fig. 11. Averaged redox profiles measured from box ( $n=9$, grey line) and gravity cores ( $n=4$, black line) collected throughout the Dunmanus Bay pockmark field and illustrating geochemical zonation of the shallow sediments in this setting. Error bars represent standard deviations in the individual profiles (SINGLE COLUMN). utilise chemosynthetic bacteria or inhabiting reduced environments (e.g. Dando et al., 1991; Jensen et al., 1992; Kiel, 2010, Ritt et al., 2011, Schmaljohann et al., 1990) were not identified from Dunmanus Bay. The lack of species known to be abundant in methane venting settings suggests that the benthic communities observed here do not rely on the intermittent supply of hydrocarbon gas.

\section{Conclusions}

The survey of the Dunmanus Bay pockmarks revealed gas related features and that an active fluid system is present in the subsurface. The uppermost sedimentary unit in Dunmanus Bay pockmark field is comprised predominantly of fine-grained sediments occasionally mixed with gravel. Pockmark features are only present where silt, clays and fine sands are the dominant substrates though there is acoustic evidence of shallow gas accumulations outside of the field. The shallow gas accumulation is laterally extended and mostly located beneath the pockmark scarred seabed, though the migration pathways are not well defined. The accumulated gas is mainly methane with a very small component of higher homologues. The methane appears to be biogenic in origin but the relative contributions of in-situ versus deep sources were not discerned. The evidence suggests that pockmarks periodically vent accumulated gas in small scale events. The magnitude of the venting and the amount of accumulated methane in the sediments suggests that methane contribution to the water column from the Dunmanus Bay field is minimal and might have only regional implications. The benthic communities were dominated by four common species and overall show structures typical 
for the sublittoral environment around Ireland. Organisms frequently encountered in areas with methane gas seepages were not common, indicating insufficient methane concentrations to alter the benthic communities in this setting.

\section{Acknowledgements}

Authors wish thank the Geological Survey of Ireland, INFOMAR programme and Irish Research Council for funding this research. The survey was carried out under the Sea Change strategy with the support of the Irish Marine Institute and the Marine Research Subprogramme of the National Development Plan 2007-2013. The authors wish to thank the crew and the captain of RV Celtic Voyager for their assistance and efforts in testing new equipment. We finally wish to thank Mr. Graham Ryan, Prof. Øyvind Hammer and an anonymous reviewer whose suggestions greatly improved the manuscript.

\section{References}

Andrews, B.D., Brothers, L.L., Barnhardt, W.A., 2010. Automated feature extraction and spatial organization of seafloor pockmarks, Belfast Bay, Maine, USA. Geomorphology 124, 55-64.

Berkson, J., Clay, C.S., 1973. Possible syneresis marine system study of late Quaternary sedimentation origin of valleys on the floor of Lake Superior. Nature 245, 89-91. http://dx.doi.org/10.1038/245089a0.

Borowski, W.S., Paul, C.K., Ussler III, W., 1996. Marine pore water sulphate profiles indicate in situ methane flux from underlying gas hydrate. Geology 24, 655-658. http://dx.doi.org/10.1130/0091-7613(1996)024 < 0655: MPWSPI > 2.3.CO;2.

Brothers, L.L., Kelley, J.T., Belknap, D.F., Barnhardt, W.A., Andrews, B., Legere, C. Clarke, J.H., 2012. Shallow stratigraphic control on pockmark distribution in north temperate estuaries. Mar. Geol. 329-331, 34-45. http://dx.doi.org/ 10.1016/j.margeo.2012.09.006.

Buchanan, J.B., 1964. A comparative study of some features of the biology of Amphiura filiformis and Amphiura chiajei [Ophiuroidea] considered in relation to their distribution. J. Mar. Biol. Assoc. 44, 565-576. http://dx.doi.org/10.1017/ S0025315400027776.

Burnett, W.C., Bokuniewicz, H., Huettle, M., Moore, W.S., Taniguchi, M., 2003. Groundwater and pore water inputs to the coastal zone. Biogeochemistry 66 3-33. http://dx.doi.org/10.1023/B:BIOG.0000006066.21240.53.

Cai, W.-J., Sayles, F.L., 1996. Oxygen penetration depths and fluxes in marine sediments. Mar. Chem. 52, 123-131. http://dx.doi.org/10.1016/0304-4203(95) 00081-X.

Cathles, L.M., Zheng, S., Chen, D., 2010. The physics of gas chimney and pockmark formation, with implications for assessment of seafloor hazards and gas sequestration. Mar. Pet. Geol. 27, 82-91. http://dx.doi.org/10.1016/j. marpetgeo.2009.09.010.

Christodoulou, D., Papatheodorou, G., Ferentinos, G., Masson, M., 2003. Active seepage in two contrasting pockmark fields in the Patras and Corinth gulfs, Greece. Geo-Mar. Lett. 23, 194-199. http://dx.doi.org/10.1007/s00367-0030151-0.

Clarke, K.R., Green, R.H., 1988. Statistical design and analysis for a 'biological effects' study. Mar. Ecol. Prog. Ser. 46, 213-226. http://dx.doi.org/10.3354/meps046213.

Clarke, K.R., Warwick, R.M., 2001. Change in Marine Communities: an Approach to Statistical Analysis and Interpretation, 2nd edition. PRIMER-E, Plymouth.

Croker, P.F., Kozachenko, M., Wheeler, A.J., 2005. Gas-related seabed structures in the western Irish Sea (IRL-SEA6). Strategic Environmental Assessment, Petroleum Affairs Division, Dublin, Technical Report.

Cross, T.F., Southgate, T., 1983. An approach to ecological monitoring in the rocky intertidal: a survey of Bantry Bay and Dunmanus Bay, Ireland. Mar. Environ. Res. 8, 149-163. http://dx.doi.org/10.1016/0141-1136(83)90048-X.

Dandapath, S., Chakraborty, B., Karisiddaiah, S.M., Menezes, A., Ranade, G., Fernandes, W., Naik, D.K., Prudhvi Raju, K.N., 2010. Morphology of pockmarks along the western continental margin of India: employing multibeam bathymetry and backscatter data. Mar. Pet. Geol. 27, 2107-2117. http://dx.doi.org/ 10.1016/j.marpetgeo.2010.09.005.

Dando, P.R., Austen, M.C., Burke Jr, R.A., Kendal, M.A., Kennicutt II, M.C., Judd, A.G., Moore, D.C., O'Hara, S.C.M., Schmaljohann, R., Southward, A.J., 1991. Ecology of a North Sea pockmark with an active methane seep. Mar. Ecol. Prog. Ser. 70, 49-63. http://dx.doi.org/10.3354/meps070049.

Devaud, M., Hocquet, T., Bacri, J.-C., Leroy, V., 2008. The Minnaert bubble: an acoustic approach. Eur. J. Phys. 29, 1263. http://dx.doi.org/10.1088/0143-0807/ 29/6/014.

Edwards, A., Jones, K., Graham, J.M., Griffiths, C.R., MacDougall, N., Patching, J., Richard, J.M., Raine, R., 1996. Transient coastal upwelling and water circulation in Bantry Bay, a ria on the south-west coast of Ireland. Estuar. Coast. Shelf Sci. 42,
213-230. http://dx.doi.org/10.1006/ecss.1996.0016.

Elliott, A.J., Clarke, T., 1991. Seasonal stratification in the NW European shelf seas. Cont. Shelf Res. 11, 467-492. http://dx.doi.org/10.1016/0278-4343(91)90054-A.

Faber, E., Stahl, W., 1984. Geochemical surface exploration for hydrocarbons in the North Sea. Bull. Am. Assoc. Pet. Geol. 68, 363-386.

Fader, G.B.J., 1991. Gas-related sedimentary features from the eastern Canadian continental shelf. Cont. Shelf Res. 11, 1123-1153. http://dx.doi.org/10.1016/ 0278-4343(91)90094-M.

Ferrin, A., Duran, R., Diez, R., Garcia-Gil, S., Vilas, F., 2003. Shallow gas features in the Galician Rias Baixas (NW Spain). Geo-Mar. Lett. 23, 207-214. http://dx.doi org/10.1007/s00367-003-0158-6.

Floodgate, Judd, A.G., G.D., 1992. The origins of shallow gas. Cont. Shelf Res. 12, 1145-1156. http://dx.doi.org/10.1016/0278-4343(92)90075-U.

Gal'chenko, V.F., Lein, A.Yu, Ivanov, M.V., 2004. Methane content in the bottom sediments and water column of the Black Sea. Microbiology 73, 211-223. http: //dx.doi.org/10.1023/B:MICI.0000023991.50280.58.

Garcia, M.L., Masson, M., 2004. Environmental and geologic application of solidstate methane sensors. Environ. Geol. 46, 1059-1063. http://dx.doi.org/10.1007/ s00254-004-1093-1.

Gribble, K.E., Nolan, G., Anderson, D.M., 2007. Biodiversity, biogeography and potential trophic impact of Protoperidinium spp. (Dinophyceae) off the southwestern coast of Ireland. J. Plankton Res. 29, 931-947. http://dx.doi.org/ 10.1093/plankt/fbm070.

Gontz, A.M., Belknap, D.F., Kelley, J.T., 2002. Seafloor features and characteristics of the Black Ledges area, Penobscot Bay, Maine, USA. J. Coast. Res. 36 (S1), 333-339.

Gray, J.S., 2002. Species richness of marine soft sediments. Mar. Ecol. Prog. Ser. 244 285-297. http://dx.doi.org/10.3354/meps244285.

Hagen, R.A., Vogt, P., 1999. Seasonal variability in shallow biogenic gas in Chesapeake Bay. Mar. Geol. 158, 75-88. http://dx.doi.org/10.1016/S0025-3227(98) 00185-6.

Harringotn, P.K., 1985. Formation of pockmarks by pore-water escape. Geo-Mar Lett. 5, 193-197. http://dx.doi.org/10.1007/BF02281638.

Hedberg, H.D., 1980. Methane generation and petroleum migration. In: Roberts, W H., Cordel, R.J. (Eds.), Problems of petroleum migration, AAPG Studies in Geology, vol. 10; 1980, pp. 179-206.

Hensen, C., Zabel., M., Pfeifer, K., Schwenk, T., Kasten, S., Riedinger, N., Schulz, H.D. Boetius, A., 2003. Control of sulphate pore-water profilesby sedimentary events and the significance of anaerobic oxidation of methane for the burial of sulphur in marine sediments. Geochm. Cosmochim. Acta 67, 2631-2647. http://dx.doi. org/10.1016/S0016-7037(03)00199-6.

Holmes, M.E., Sanosone, F.J., Rust, T.M., Popp, B.N., 2000. Methane production, consumption, and air-sea exchange in the open ocean: An evaluation based on carbon isotopic ratios. Global Biogeochem. Cycles 14, 1-10. http://dx.doi.org/ 10.1029/1999GB001209.

Hovland, M., Judd, A.G., King, L.H., 1984. Characteristic features of pockmarks on the North Sea floor and Scotian Shelf. Sedimentology 31, 471-480. http://dx.doi. org/10.1111/j.1365-3091.1984.tb01813.x.

Hovland, M., Judd, A.G., 1992. The global production of methane from shallow submarine sources. Cont. Shelf Res. 12, 1231-1238. http://dx.doi.org/10.1016/ 0278-4343(92)90082-U.

Hovland, M., Gallagher, J.W., Clennell, M.B., Lekvam, K., 1997. Gas hydrate and free gas volumes in marine sedimenst: examples from the Niger Delta front. Mar. Pet. Geol. 14, 245-255. http://dx.doi.org/10.1016/S0264-8172(97)00012-3.

Hovland, M., Heggland, R., De Vries, M.H., Tjelta, T.I., 2010. Unit-pockmarks and their potential significance for predicting fluid flow. Mar. Pet. Geol. 27, 1190-1199. http://dx.doi.org/10.1016/j.marpetgeo.2010.02.005.

Hovland, M., Jensen, S., Indreiten, T., 2012. Unit pockmarks associated with Lophelia coral reefs off mid-Norway: more evidence of control by 'fertilizing' bottom currents. Geo-Mar. Lett. 32, 545-554. http://dx.doi.org/10.1007/s00367-0120284-0.

Hunt, R., 1858. Memoirs of the Geological Survey of Britain, and of the Museum of Practical Geology. Geological Survey of Great Britain, London, p. 867.

Jenkinson, I.R., Connors, P.P., 1980. The occurrence of the red tide causing organism, Gyrodinium aureolum, Hulbert (Dinophyceae), round the south and west of Ireland in August and September, 1979. J. Sherkin Island 1, 127-146.

Jensen, P., Aagaard, I., Burke Jr, R.A., Dando, P.R., Jorgensen, N.O., Kuijpers, A., Laier T., O'Hara, S.C.M., Schmaljohann, R., 1992. 'Bubbling reefs' in the Kattegat: submarine landscapes of carbonate-cemented rocks support a diverse ecosystem at methane seeps. Mar. Ecol. Prog. Ser. 83, 103-112.

Judd, A.G., Davies, G., Wilson, J., Holmes, R., Baron, G., Bryden, I., 1997. Contributions to atmospheric methane by natural seepages on the UK continental shelf. Mar Geol. 140, 427-455. http://dx.doi.org/10.1016/S0025-3227(96)00087-4.

Judd, A.G., 2003. The global importance and context of methane escape from the seabed. Geo-Mar. Lett. 23, 147-154. http://dx.doi.org/10.1007/s00367-0030136-Z.

Judd, A.G., 2004. Natural seabed gas seeps as sources of atmospheric methane. Environ. Geol. 46, 988-996. http://dx.doi.org/10.1007/s00254-004-1083-3.

Judd, A.G., Hovland, M., 2007. Seabed Fluid Flow: The Impact on Geology, Biology, and the Marine Environment. Cambridge University Press, New York, p. 475.

Jukes, J.B., Kinahan, G.H., Du Noyer, G.V., Baily, W.H., Kinahan, G.H., Foot, F.J., O’Kelly, J., Wynne, A.B., Kelley, J., Galvan, C., McHenry, A., 1861. Explanations to accompany Sheets 200, 203, 204 and 205, and part of 199 of the map of the Geological Survey of Ireland illustrating part of the County Cork. Memoirs of the Geological Survey of Ireland, London, pp. 05-28.

Jukes, J.B., 1864. Explanation to accompany Sheet 192 and part of Sheet 199 of the 
map of the Geological Survey of Ireland illustrating part of the County Cork and Kerry. Memoirs of the Geological Survey of Ireland, London, pp. 5-51.

Keegan, B.F., Mercer, J.P., 1986. An oceanographical survey of Killary Harbour on the West Coast of Ireland. Proc. R. Ir. Acad. Sect. B: Biol. Chem. Sci. 86B, 1-70.

Kelley, J.T., Dickson, S.M., Belknap, D.F., Barnhardt, W.A., Henderson, M., 1994. Giant sea-bed pockmarks: evidence for gas escape from Belfast Bay, Maine. Geology 22, 59-63. http://dx.doi.org/10.1130/0091-7613(1994)022 < 0059: GSBPEF $>$ 2.3.CO;2.

Kiel, S., 2010. The vent and seep biota. In: Landman, N.H., Harries, P. (Eds.), Topics in Geobiology, 33. Springer, Germany, p. 487.

King, L.H., MacLean, B., 1970. Pockmarks of the scotian shelf. Geol. Soc. Am. Bull. 81, 3141-3148. http://dx.doi.org/10.1130/0016-7606(1970)81[3141:POTSS]2.0.CO;2.

King, G.M., Klug, M.J., Lovley, D.R., 1983. Metabolism of acetate, methanol, and methylated amines in intertidal sediments of Lowes Cove, Maine. Appl. Environ. Microb. 45, 1848-1853.

Khandriche, A., Werner, F., 1995. Freshwater induced pockmarks in Bay of Eckernforde, western Baltic, In: Mojski, J.E., Malecka, J., (Eds) Proceedings of 3rd Marine Geological Conference 'The Baltic'. Panstwowy Instytut Geologiczny, Warsaw, pp. 155-164.

Kruskal, J.B., Wish, M., 1978. Multidimensional Scaling. Sage University Paper series on Quantitative Applications in the Social Sciences. Sage Publications, Newbury Park, CA, pp. 07-011, number.

Kutas, R.I., Paliy, S.I., Rusakov, O.M., 2004. Deep faults, heat flow and gas leakage in the northern Black Sea. Geo-Mar. Lett. 24, 163-168. http://dx.doi.org/10.1007/ s00367-004-0172-3.

MacCarthy, I.A.J., 2007. The South Munster Basin of southwest Ireland. J. Maps 2007, 149-172. http://dx.doi.org/10.1080/jom.2007.9710835.

McMahon, T.E., Zale, A.V., Orth, D.J., 1996. Aquatic habitat measurements. In: Murphy, B.R., Willis, D.W. (Eds.), Fisheries Techniques, 2nd ed. American Fisheries Society, Bethseda, p. 732.

Monteys, X., Garcia, X., Szpak, M., Garcia-Gil, S., Kelleher, B., O’Keeffe, E., 2008. Multidisciplinary approach to the study and environmental implications of two large pockmarks on the Malin Shelf, Ireland. In: Proceedings of the 9th International Conference on gas in marine sediments, Bremen, Germany.

Monteys, X., Garcia, X., Evans, R., Kelleher, B., Szpak, M., O’Keffee, E. 2009. Geohazard Seabed Mapping in the Malin Shlef, NW Ireland. Scientific Report, GSI/PIP - IS05/16.

Monteys, X., M., Bloomer, S., Chapman, R., 2010. Multi-frequency acoustic seabed characterization in shallow gas bearing sediments in Dunmanus Bay, SW Ireland. Geophysical Research Abstracts 12, EGU2010-10707-2.

Moss, J.L., Cartwright, J., Cartwright, A., Moore, R., 2012. The spatial pattern and drainage cell characteristics of a pockmark field, Nile Deep Sea Fan. Mar. Pet. Geol. 35, 321-336. http://dx.doi.org/10.1016/j.marpetgeo.2012.02.019.

Naylor, D., 1975. Upper Devonian-Lower Carboniferous stratigraphy along the south coast of Dunmanus Bay, Co. Cork. Proc. R. Ir. Acad. 75, 317-337.

Naylor, D., Sevastopulo, G.D., 1993. The reenydonagan formation (Dinantian) of the Bantry and Dunmanus Synclines, County Cork. Ir. J. Earth Sci. 12, 191-203.

Newman, K.R., Cormier, M.-H., Weissel, J.K., Driscoll, N.W., Kastner, M., Solomon, E. A., Robertson, G., Hill, J.C., Singh, H., Camilli, R., Eustice, R., 2008. Active methane venting observed at giant pockmarks along the U.S. mid-Atlantic shelf break. Earth Planet. Sci. Lett. 267, 341-352. http://dx.doi.org/10.1016/j. epsl.2007.11.053.

O’Reilly, S.S., Hryniewicz, K., Little, C.T.S., Monteys, X., Szpak, M.T., Murphy, B.T., Jordan, S.F., Allen, C.C.R., Kelleher, B.P., 2014. Shallow methane-derived authigenic carbonate mounds at the Codling Fault Zone, western Irish Sea. Mar. Geol. 357, 139-150. http://dx.doi.org/10.1016/j.margeo.2014.08.007.

O’Sullivan, D., Lordan, C., Doyle, J., Berry, A., Lyons, K., 2014. Sediment characteristics and local hydrodynamics and their influence on the population of $\mathrm{Ne}$ phrophs around Ireland. Marine Institute, Ireland, p. 33, Irish Fisheries Investigations No. 24.

Pau, M., Hammer, Ø., 2013. Sediment mapping and long-term monitoring of currents and sediment fluxes in pockmarks in the Oslofjord, Norway. Mar. Geol. 346, 262-273. http://dx.doi.org/10.1016/j.margeo.2013.09.012.

Paull, C.K., Hecker, B., Commeau, R., Freeman-Lynde, R.P., Neumann, C., Corso, W.P., Golubic, S., Hook, J.E., Sikes, E., Curray, J., 1984. Biological communities at Florida Escarpment resemble hydrothermal vent taxa. Science 226, 965-967. http://dx.doi.org/10.1126/science.226.4677.965.

Pielou, E.C., 1977. Mathematical Ecology. Wiley, New York, p. 385. http://dx.doi.org/ 10.1002/bimj.4710200616.

Pilcher, R., Argent, J., 2007. Mega-pockmarks and linear pockmark trains on the West African continental margin. Mar. Geol. 244, 15-32. http://dx.doi.org/ 10.1016/j.margeo.2007.05.002.

Plets, R., Callard, L., Cooper, A., Long, A., Belknap, A., Edwards, R., Derek, J., Kelley, J., Long, D., Milne, G., Monteys, X., Quinn, R., 2014. Deglacial and post-glacial sealevel history for the Bantry Bay (SW Ireland) based on offshore evidence. Geophysical Research Abstracts 16, EGU2014-5164.

Raine, R., O’Mahony, J., McMahon, T., Roden, C., 1990. Hydrography and phytoplankton of waters off south-west Ireland. Estuar. Coast. Shelf Sci. 30, 579-592. http://dx.doi.org/10.1016/0272-7714(90)90094-8.

Ritt, B., Pierre, C., Gauthier, O., Wenzhofer, F., Boetius, A., Sarrazin, J., 2011. Diversity and distribution of cold-seep fauna associated with different geological and environmental settings at mud volcanoes and pockmarks of the Nile Deep-Sea Fan. Mar. Biol. 158, 1187-1210. http://dx.doi.org/10.1007/s00227-011-1679-6.

Roden, C.M., Ryan, T., Lennon, H.J., 1980. Observations of the 1978 red tide in Roaringwater Bay, Co. Cork. J. Sherkin Island 1, 105-118.

Roden, C.M., Lennon, H.J., Mooney, E., Leahy, P., Lart, W., 1981. Red tides, water stratification and species succession around Sherkin Islands, S.W. Ireland. J. Sherkin Island 1, 50-68.

Rosenberg, R., 2001. Marine benthic faunal successional stages and related sedimentary activity. Sci. Mar. 65 (Suppl. 2), S107-S119.

Schmaljohann, R., Faber, E., Whiticar, M.J., Dando, P.R., 1990. Co-existence of methane- and sulphur-based endosymbioses between bacteria and invertebrates at a site in the Skagerrak. Mar. Ecol. Prog. Ser. 61, 119-124.

Silverman, B.W., 1986. Density estimations for statistics and data analysis. Monographs on statistics and applied probability. 26. Chapman \& Hall, New York, p. 1751986.

Skarke, A., Ruppel, C., Kodis, M., Brothers, D., Lobecker, E., 2014. Widespread methane leakage from the sea floor on the northern US Atlantic margin. Nat. Geosci. 7, 657-661. http://dx.doi.org/10.1038/ngeo2232.

Somerfield, P.J., Clarke, K.R., 1997. A comparison of some methods commonly used for the collection of sublittoral sediments and their associated fauna. Mar. Environ. Res. 43, 145-156. http://dx.doi.org/10.1016/0141-1136(96)00083-9.

Straughan, D., 1982. Observations on the effects of natural oil seeps in the coal oil point area. Philos. Trans. R. Soc. Lond.: B 297, 269-283.

Szpak, M.T., O’Connor, B., Kelleher, B.P., Monteys, X., 2009. Pockmarks groundtruthing survey in Dunmanus Bay, Co. Cork. Marine Institute, Ireland, p. 139, INFOMAR Technical Report, project CV09_23.

Szpak, M.T., Monteys, X., O’Reilly, Simpson, A.J., Garcia, X., Evans, R.L., Allen, C.C.R., McNally, D.J., Courtier-Murias, D., Kelleher, B.P., 2012. Geophysical and geochemical survey of a large marine pockmark on the Malin Shelf, Ireland. Geochem. Geophys. Geosyst., 13; p. Q01011. http://dx.doi.org/10.1029/ 2011GC003787.

Taniguchi, M., Burnett, W.C., Cable, J.E., Turner, J.V., 2002. Investigation of submarine groundwater discharge. Hydrol. Process. 16, 2115-2129. http://dx.doi. org/10.1002/hyp.1145.

Walsh, S., 2012. Climatological Note No. 14. A summary of climate averages for Ireland 1981-2010. Met Eireann, Glasnevin Hill, Dublin 9, 16pp.

Webb, K.E., Barnes, D.K.A., Gray, J.S., 2009a. Benthic ecology of pockmarks in the Inner Oslofjord, Norway. Mar. Ecol. Prog. Ser. 387, 15-25. http://dx.doi.org/ 10.3354/meps08079.

Webb, K.E., Barnes, D.K.A., Planke, S., 2009b. Pockmarks: refuges for marine benthic biodiversity. Limnol. Oceanogr. 54, 1776-1788. http://dx.doi.org/10.4319/ lo.2009.54.5.1776

Wildish, Akagi, D.J., McKeown, H.M., Pohle, G.W., D.L., 2008. Pockmarks influence benthic communities in Passamaquoddy Bay, Bay of Fundy, Canada. Mar. Ecol. Prog. Ser. 357, 51-66. http://dx.doi.org/10.3354/meps07331.

Wilson, J., Rocha, C., 2012. Regional scale assessment of Submarine Groundwater Discharge in Ireland combining medium resolution satellite imagery and geochemical tracing techniques. Remote Sens. Environ. 119, 21-34. http://dx.doi. org/10.1016/j.rse.2011.11.018.

Yun, J.W., Orange, D., Field, M.E., 1999. Subsurface gas offshore of northern California and its links to submarine geomorphology. Mar. Geol. 154, 357-368, DOI: 1016/S0025-3227(98)00123-6. 